ISSN:2528-9527

E-ISSN : 2528-9535

YIl Year: 11

Cilt Volume: 17

Sayı Issue :38

Uluslararası Toplum Araştırmaları Dergisi International Journal of Society Researches

Haziran June2021

Makalenin Geliş Tarihi Received Date: 31/12/2020

Makalenin Kabul Tarihi Accepted Date: 18/03/2021

\title{
Çalgı Performans Yönetimi Öz-Yeterlik Algısı Ölçeği Geliştirme Çalışması
}

\author{
DOI: 10.26466/opus.851048
}

\author{
Ümit Kubilay Can* - Özlem Yorulmaz Birdal** \\ *Doç. Dr., Kocaeli Üniversitesi, Güzel Sanatlar Fakültesi, İzmit/Kocaeli/Türkiye \\ E-Posta: kubican gitar@hotmail.com \\ ORCID: 0000-0001-9197-2240 \\ **Serbest Araştırmacı, İstanbul/Türkiye \\ E-Posta: ozlemmyorulmaz@gmail.com \\ ORCID: $\underline{0000-0001-9657-7848}$
}

Öz

Bu çalışmada mesleki müzik eğitimi alan öğrencilerin çalgı performans yönetiminde kendi öz-yeterlik becerilerine yönelik algıların ortaya koyabilecek bir ölçek geliştirmek amaçlanmıştır. Betimsel nitelikte ve tarama modeline uygun olarak yapılan bu çalışmada geliştirilen Çalgı performans yönetimi öz yeterlik algısı ölçeği geçerli ve güvenilir midir? Sorularına cevap aranmıştır. Araştırmanın çalışma grubunu, Marmara Üniversitesi ve Kocaeli Üniversitesi Müzik Bölümlerinde öğrenim gören toplam 150 öğrenci oluşturmaktadır. Mesleki müzik eğitimi alan öğrencilerin çalgı performans yönetim becerilerine yönelik öz-yeterlik algilarım etkileyen faktörleri ve bu faktörlere ilişkin algı düzeylerini belirlemek üzere araştırmacılar tarafindan, Türkiye'de ve yurtdışında yapılan çalışmalar incelenerek ve konunun uzmanlarından alınan görüşler çerçevesinde, beş konu başliğı altında toplam 49 maddeden oluşan, 5'li Likert tipi bir ölçek geliştirilmiştir. Çalgı Performans Yönetimi Öz-Yeterlik Algısı Ölçeğinin 47 maddesi birlikte analiz edildiğinde, genel güvenirlik katsayısının fazla olması ölçeğin bir bütün olarak da kullanılabileceğini ve güvenirlik (iç-tutarlılık) düzeyinin çok yüksek olduğunu göstermektedir. Çalgı Performans Yönetimi Öz-Yeterlik Algısı Ölçeğinin 47 madde ve beş alt boyuttan meydana geldiği, doğrulayıcı faktör analizi uyum kriterleri ile de teyit edilmiş ve bu modelin kuramsal ve istatistiksel açıdan uygun olduğu anlaşılmıştır.

Anahtar Kelimeler: Öz-yeterlik, Performans Yönetimi, Çalgı Performans, Çalgı Ĕ̆gitimi, Müzik Eğitimi. 


\title{
A Scale Development Study on the Perception of Self- Efficiency in Instrument Performance Management
}

\begin{abstract}
In this study, it was aimed to develop a scale that can reveal the perceptions of professional music education students towards their own self-efficacy skills in instrument performance management. Is the instrument performance management self-efficacy scale developed in this descriptive study conducted in accordance with the scanning model valid and reliable? Answers to their questions were sought. The study group, Marmara University and consisted of 150 students in Kocaeli University Department of Music by professional music education students musical performance management factors affecting their self-efficacy for skill and researchers to determine the level of perception related to these factors, studies in Turkey and abroad A 5-point Likert-type scale consisting of a total of 49 items under five subject headings was developed by examining and within the framework of the opinions received from experts on the subject. When the 47 items of the Instrument Performance Management Self-Efficacy Scale are analyzed together, the high overall reliability coefficient indicates that the scale can be used as a whole and the reliability (internal consistency) level is very high. The Instrument Performance Management Self-Efficacy Scale consists of 47 items and five sub-dimensions, and confirmatory factor analysis has been confirmed by the fit criteria, and it is understood that this model is theoretically and statistically appropriate.
\end{abstract}

Keywords: Self-Efficacy, Performance Management, Instrument Performance, Instrument Education, Music Education. 


\section{Giriş}

Çalgı eğitimi, bir enstrümanı çalabilmek için kullanılan yöntem ve tekniklerin öğrenilmesidir (Uçan, 2018). Mesleki müzik eğitiminin en önemli alanı çalgıdır. Kişinin istek ve fiziki durumu göz önüne alınarak seçilen bu alanda çalışmak büyük bir disiplin gerektirmektedir. Temel duruş ve tutuştan performans sergilemeye kadar adım adım çalışmalarla şekillenir. Öğrencinin yeterli temel donanıma sahip olduktan sonra çeşitli eserler çalışarak bir performans sergilemesi beklenir. Performans, bir görevin yerine getirilme eylemidir ve bir hedefe ulaşmak için elde ettiğimiz (Çorbacl, 2010; Helvac, 2002; Kalkandelen, 1997; Pugh, 1991) sonuçlardır. Buna göre tüm çalgı çalışmalarından sonra sergilenen performans süreç boyunca alınan eğitimin bir çıtısıdır. Bir çalgı ile performans sergilemek zorlu bir süreçtir ve performans sergilerken birçok sorun ile karşılaşmak olası bir durumdur. Bu sorunlar, çalgı performansı sergilenecek olan esere yeteri kadar çalışamama sonucunda yanlış ses ve nüansların ortaya çıması ile eserin akışının bozulmasına sebep olabilir. Performans sergilenen sahnede materyal, akustik vb. teknik sorunlar1nın olması da performans sergilerken karşılaşılan sorunlardan biridir (Doğan ve Tecimer, 2019). Tüm bu zorlukların üstesinden gelebilmek için kişi ruh hali ve motivasyonunu kontrol altına almalıdır. Çalgı performansında repertuar çalışmaları da öğrencinin seviyesi gözetilerek verilmelidir. Bu durumda öğretmenin öğrenci üzerindeki etkileri de büyük önem taşımaktadır. Öğretmenin öğrenci seviyesine uygun eserler vermesi gerekir. Öğrenci zorlandığ eserleri çalışmaktan keyif alamadığı zaman kendisini geliştiremez ve çalg1sindan soğumaya başlar. Bunun için öğrencinin seviyesine uygun görev niteliği taşıyan performans eserleri seçilebilir. Görev niteliği taşıyan performans eserleri, konser eserleri veya sinav eserleri olarak belirlenebilir. Bu çalışmanın bir görev niteliği taşıması öğrencinin belli bir süreye kadar çalışmalarının tamamlanması gerektiğinden öğrenciyi belirli hedefler belirlemeye itmektedir. Öğrenci sınırlanan zamanda sergilemesi gereken eserleri çalışırken bir yandan da kendi ilerleyişini izlemektedir. Böylece hedef belirlemenin yanında kendini değerlendirme kazanımını da elde etmiş olur. İyi bir performans için çalışmaların hedefler doğrultusunda planlanması gerekir. Bireyin vizyonu ve yeteneklerini de geliştiren bu süreçte performans yönetimi, ulaşılmak istenen hedefleri başarılı bir biçimde ortaya çıkarır. Öztürk (2006), per- 
formans yönetiminin temelinde, bireylerin kendi sorumluluklarının bilincinde olup anlaşlabilen ve ulaşlabilen hedeflerin istenilen hedeflerle uyum içerisinde olması gerektiğini vurgular. Bireyin motivasyonunun sağlanması ve desteklenmesi ile istenilen çalgı performansı sergilenebilir. Çalg1 performans yönetiminde planlama ve kontrol ile olumlu yönde gelişmeler gözlenebilir. Birey bu süreçte eksikliklerini görerek kendi performansını geliştirebilir. Böylece kişi kendini tanır ve yapabileceklerinin farkına varır (Yolcu, 2008). Bir çalgı performansına hazırlanırken, performansın gerçekleşeceği zamana kadar öğrencinin çalgı çalışma disiplini, süresi ve isteği doğrultusunda kendisini planlaması gerekir. Çalgı Performansı Yönetiminde istenilen hedeflere ulaşabilmek için yapılan planlamalar bu çalışmada olduğu gibi; Kariyer Yönetimi, Zaman Yönetimi, Sahne yönetimi, Yürütücü biliş ve Motivasyon gibi çeşitli boyutlar çerçevesinde düzenlenebilir.

Kariyer, bireyin seçtiği meslek dalındaki ilerleyişindeki aktivite, aldığı sorumluluk ve davranışlar bütünüdür (Baydoğan, 2007; Çelik ve Akgemci, 1998; Ivancevich, Donelly, ve Gibson, 1980; Taştepe, 2001). Kariyer Yönetimi, bireyin mevcut bulunduğu mesleki konumunun farkında olup, ileride neler olabileceğini öngörmesi, bunun için hazırlıklar yaparak kendisini gelecekteki istediği statüye ulaştırmasını sağlar. Kariyer Yönetimi sayesinde birey, verimliliği arttırarak istediği hedeflere daha hılı ulaşıp kendisine daha iyi bir iş olanağı sağlamış olur (Fındıkçı, 1999). Bireysel Kariyer Yönetiminde amaç; bireyin ilgi, yetenek ve iş yaşamındaki beklentilerine uygun hedefler (Gül ve Avc1, 2018; Okakın, 2008) belirlemektir. Çalgı performansında birey, planladığı kariyer yönetiminde uzun ve kısa vadeli hedefler belirlemeli, kendini gözlemleyebilme ve değerlendirme yapabilmelidir. Bireyin eksikliklerini farkedip bu ihtiyaçlarına uygun olarak kariyerini planlaması gerekir. Ayrıca alanıyla ilgili güncel etkinlik ve gelişmeleri takip ederek kariyerine doğru adımlarla ve kendinden emin olarak yön verip, planlamalar yapabilir. Kariyer yönetiminde bireyin, zamanı doğru kullanıp ona göre bir program hazırlaması hedeflerine daha kısa sürede ulaşmasını sağlar. "Zamanın etkili ve verimli kullanımı bireyin amaca yönelik planlama yapması ve yürütmesi ile gerçekleşebilir ki bu durum zaman yönetimi kavramıla doğrudan ilişkilidir"' (Babacan ve Küçükosmanoğlu, 2015, s.36).

Zaman Yönetimi belirlediğimiz amaçlar çerçevesinde öncelik sırasına göre yapacağımız çalışmaları planlamak ve bu planlara uyup kendimizi (Peeters ve Rutte, 2005) gözlemlememizdir. Ayrıca zaman yönetimi, sergilemek 
istediğimiz performansın istenen zamanda gerçekleşmesini sağlamak amacryla programlamaların uygulanmasını içermektedir. Zaman, kontrol altına alamadığımız bir olgudur. Bu yüzden zaman iyi planlanmadığında birey panikleyebilir ve tedirgin hissedebilir. Bu durum sergilenen performansı olumsuz etkileyebilir (Taner, 2005). Çalgı performansımızı planlarken zamanı en etkin şekilde kullanmamız büyük önem taşır. Fakat bazen çalışmaları olumsuz etkileyen durumlar meydana gelebilir. Öncelikle amaçlanan hedefler doğrultusunda zamanın planlanamaması ya da yanlış planlama yapılması ve çalınacak eserlerin önem ve öncelik sırasına uygun çalışılmaması istenilen sonuçların alınamamasına sebep olabilir. Çalışma esnasında ziyaretçilerin gelmesi, telefon bağımlılığı ve çalışma ortamının gürültülü olması zamanı olumsuz etkileyen etmenler arasındadır. Öncelikli olarak belirli hedeflerin belirlenmemesi ya da hedeflerde kararsızlık durumu çalgıda performansın beklenen zamanda istenilen düzeyde sergilenmemesine neden olur. Bu yüzden performans sergileyebilmesi için bireyden, çalgı çalışmasını da planlayarak yönetmesi beklenir.

Çalg1 Çalışma Yönetimi belirlenen hedefler doğrultusunda sergilenecek olan performansın hazırlık sürecine uygulanacak teknik, çevresel, zamansal, fiziksel planlamaların bütünüdür. Düzenli teknik çalışmalar performans öncesi kondisyonu sağlar ve daha rahat bir çalım meydana gelir (Özçimen ve Barubatur, 2012). Çalışma ortamının bireyin dikkatini dağıtmayacak şekilde düzenlenmesi çalışmanın uzun süreler boyunca kesintisiz devam etmesine olanak sağlar. Belirlenen hedeflerde istikrarlı olunması ve bu yolda gerekli materyallerin doğru ve etkin bir şekilde kullanılması çok önemlidir. Yağışan (2004), bir çalışmaya başlamadan önce bedeni uzun sürecek çalışmaya hazırlamak için çeşitli ısınma ve gevşeme hareketlerinin düzenli yapılması daha sonra ortaya çıkabilecek sakatlanma ve rahatsızlıkların da önüne geçeceğini belirtir. Tüm bu planlamaların yanı sıra performansın sergileneceği ortam da çok önemlidir.

Performans sergilenen sahnenin materyal, akustik vb. teknik sorunlarının olması da performans sergilerken karşılaşılan sorunlardan biri (Doğan ve Tecimer, 2019) olabilir. Bu sorunlardan etkilenmemek için sahne yönetiminde hakimiyet sağlanmalıdır. Sahnenin doğru kullanımı ve akustik dağılımı sergilenen performansın daha iyi görünmesini ve duyulmasını sağlar. Sahnede performans ile birlikte performans sergileyen kişinin görünümü de önemlidir. Sahne üzerinde kişilerin kılık-kıyafet açısından estetik ve düzenli olması 
hem yapılan işlerin önemi hem de seyirciye ve bireyin kendisine ait saygısını gösterir. Sahnede meydana gelebilecek teknik sorunlardan ziyade bireyde oluşan kaygı, korku gibi ruhsal değişimler de sahne performansını etkileyen zorluklardır (Çırakoğlu, 2013). Tüm bu zorlukların üstesinden gelebilmenin bir yolu da yürütücü biliş becerisidir. Böylece birey kendi durumunun farkına vararak, ruh hali ve motivasyonunu kontrol altına alabilir.

Butler ve McManus (1998)'e göre yürütücü biliş, bireyin kendi yapabilirliklerinin farkına varmasıdır. Yürütücü biliş ile öğrenilen bilgilerin işlenmesi, bu bilgilerin kontrol ve düzenlemesi tamamen bireyin elindedir (Senemoğlu, 2007). Birey kendi öğrenmelerinin ve neyi nasıl öğrenebileceğinin bilgisine (Slavin, 2000) sahiptir. Öğrenme sırasında bir sonraki aşamada neler olabileceğinin tahminine varır. Bu durumda anlamlı ve anlamsız olarak öğrenilen bilgiyi ayırt etme yeteneğine de sahip olur (Altındağ, 2008). Öğrenenin nasıl öğrendiği veya öğreneceği ile sergileyeceği performansı arasında doğrudan ilişki (Pintrich, 2002) içerisindedir. Yürütücü biliş becerisi kuvvetli olan birey öğrenmelerinde neyin nasıl olacağı konusunda planlamalar yapar. Çalışmalarında ne kadar zamana ihtiyacı olduğunu tahmin eder. Öğrenme sırasında performansını kontrol ederek kendisini başarı ile motive eder (Senemoğlu, 2007). Bu tanımlamalara göre birey çalgı performansı sergilemeden önce hangi eseri nasıl çalışması gerektiğini, bu çalışmanın ne kadar sürede sonlanacağını ve çalışmanın iyi veya kötü ilerlediğine dair görüşlere sahip olur. Tüm bu planlamalarla da kendisini motive ederek daha verimli bir çalışma sağlar.

Motivasyon bireyin bir amacı gerçekleştirmek için gösterdiği içsel davranışlardır (Daft, 1997). Belirlenen görev niteliğindeki hedeflerin zorluk ve kolaylık durumu da motivasyonu etkileyen unsurlardır. Görev ne kadar zorlu olursa motivasyon da o kadar güçlü olur. Motivasyon gayret, performans ve verimlilik gibi gözlenebilen sonuçlarla anlaşlabilir (Hewett, 2016). Kişiyi motive eden temel unsur ise ihtiyaçtır. Birey belli süreç çerçevesinde hedeflere uygun olarak ihtiyacına karşıllk kendi motivasyonunu geliştirir (Deci ve Ryan, 2000). Bireyi kendisi dışında çevresel unsurlar da motive edebilir. Mesleki müzik eğitiminde öğrencinin motive olması performansı için çok önemlidir. Bu konuda en yardımcı olacak kişi öğretmendir. Öğretmen öğrenciye karşı tutum ve davranışları ile öğrenci arasında güçlü bir bağ kurmalıdır. Ö̆̆retmenin alanında yetkinliğinin fazla olması öğrencisine aktaracağı bilgilerin doğru şekilde anlaşılmasını sağlar. Aile ve arkadaşların öğrenciye verdiği her 
türlü destek öğrencinin kendine güvenmesi ve kendisine doğru hedefler belirlemesi için önemlidir. Ebeveynlerin öğrencinin yetenekleri doğrultusunda seçeceği alanı desteklemesi öğrencinin sergileyeceği performansına dair motivasyonunu yükseltir.

Çalgı performans yönetimi için kariyer, zaman, çalgı çalışma, sahne, yürütücü biliş ve motivasyon boyutlarının planlanması ışığında birey her yeni performans sergileme durumunda kendi öz-düzenleme ve öz- değerlendirmesini yaparak alanında yetkinleşebilmektedir.

Bireyin kendi yeteneklerinin farkına varması ve kişilik özelliklerine karşı her türlü algısı "Öz" ü ifade eder. Öz kavramı kişinin kendini tanımasını sağlar. Öz-yeterlik bir çalışma alanını isteyerek seçme, o işi başarabilmek için büyük bir motivasyon hissetme, çaba gösterme ve o çalışma üzerinde zaman harcama gibi sonuçları doğurmaktadır (Akkoyunlu ve Orhan, 2003, s.86). Arseven (2016)' ya göre “ öz-yeterlik algıları, insanların motivasyon ve davranışlarının önemli bir parçasını oluşturmakla kalmaz kişilerin yaşamlarını değiştirebilecek eylemleri de etkiler" (67). Bandura (1995)'ya göre öz-yeterlik kişinin yeteneklerine olan inancını ifade eder. Çalışmalarını yönetmek için gerekli eylem planlarını organize ederek uyguladığı bir süreçtir. Algılanan özyeterlik ne kadar güçlü ise insanların kendilerine koydukları hedefler daha (Locke ve Latham, 1990; Albayrak, Bulut, 2020) zorludur. Öz-yeterlik duygusu güçlü olanlar performans için olumlu tahminlerde bulunup motive olurlar. Fakat öz-yeterliğinden şüphe edenler olumsuz düşünceleri yüzünden başarısızlık yaşarlar (Bandura, 1995). Bireyin karşılaştığı problemlerin çözümünde öz-yeterliğin dört temel kaynağından (Bıkmaz, 2004; Kan, 2014; Kutlucan, 2018; Dilmaç ve İnanç, 2015) yararlanılabilir. Kan (2014)'a göre özyeterliğin en etkili kaynağı bireyin kendi deneyimleridir. Geçmişte edindiği başarı ve başarısızlık durumu gelecekteki inançlarını etkiler. Güçlü bir öz-yeterlik inancı tekrarlanan başarı sayesinde sağlanır. Öz-yeterliğin ikinci kaynağı olan dolaylı deneyimlerde kişinin tanık olduğu, kendi durumuna yakın gördüğü bir modelin deneyimlerini kendi gelecekteki deneyimlerine (Arseven, 2016; Akkoyunlu ve Orhan,2003; Yurt ve Kurnaz, 2015; Otacığlu, 2017; Gün ve Büyükgöze, 2015; Kan, 2014) benzetmesidir. Bireyin kendisine olan şüphesi ve yetersiz deneyimleri onu daha çok dolaylı deneyime itmektedir. Öz-yeterlik inancını sadece deneyimler etkilememektedir. Kişinin motivasyonu, bireye verilen nasihatler, güzel sözler, cesaret verici hareketler de özyeterliğin kaynaklarından biridir. İkna yoluyla bireyin öz-yeterlik inancında 
değişmeler meydana gelir. Bireyin belirli sebepler sonucunda yaşadığı stres, yorgunluk, korku ve fizyolojik rahatsızlar yani psikolojik durumu da öz-yeterliği etkiler. Öz-yeterliği yüksek olan bir bireyin performans sergileyeceği zaman yaşadığı çeşitli ağrılar performansı dolayısıyla öz-yeterliği üzerinde değişime sebep olur.

Öğrencinin ne kadar konser verdiği ve sergilemiş olduğu performansı da öz-yeterlik durumunu ortaya koymaktadır. Öğrenci kendisini ve çaldığı eseri sergilerken performansı ile değerlendirilir. Bundan dolayıdır ki çalgı eğitiminin en önemli boyutu çalgı performansıdır (Albayrak ve Bulut, 2020).

Müzik alanından yapılan öz-yeterlik ölçeği ile ilgili literatüre bakıldığında, Yıldız (2014), “Müziksel İşitme, Okuma ve Yazma Öz- Yeterlik Ölçeğinin Geliştirilmesi ve Müzik Öğretmeni Adaylarının Öz- Yeterlik Düzeylerinin Bazı Değişkenler Açısından İncelenmesi." Gün, (2014), "Piyano Performansı Öz-Yeterlik Ölçeğinin Geliştirilmesi ve Uygulanması." Şeker (2016), "Çalgı Performansına İlişkin Öz-Yeterlik Ölçeğinin Geliştirilmesi” başlıklı çalışmalar göze çarpmaktadır.

\section{Problem}

Eğitim alanında yapılan bu çalışmada Müzik Bölümü öğrencilerin çalgı performans yönetimi öz-yeterlik algılarını ortaya çıkarmak için bir ölçme aracının gerekliliği hissedilmiştir. Çalgı performans yönetimine dair geniş kapsamlı ölçeklerin olmaması bu çalışmanın problemi olarak belirlenmiştir.

\section{Amaç}

Bu çalışmanın amacı, mesleki müzik eğitimi alan öğrencilerin çalgı performans yönetiminde kendi öz-yeterlik becerilerine yönelik algılarını ortaya koyabilecek bir ölçek geliştirmektir. Bu amaç doğrultusunda çalışmada, Kariyer Yönetimi, Zaman yönetimi, Sahne yönetimi, Çalg1 Çalışma Yönetimi, Yürütücü biliş ve Motivasyon olarak beş boyuta göre hazırlanan önermelerle Çalgı Performans Yönetimi Öz-Yeterlik Algısı ölçeği geliştirmek planlanmıştır.

Araştırmanın genel amacına yönelik olarak oluşturulan "Çalg1 performans yönetimi öz-yeterlik algısı ölçeği, geçerli ve güvenilir bir ölçek midir?" alt amaç sorusuna çalışmada cevap aranmıştır. 


\section{Önem}

Müzik alanında ilerlemek ve başarılı olabilmek için disiplinli ve planlı bir çalışma gerekmektedir. Bireyin kendi öz- düzenlemesini yaparak geliştirdiği bilişsel ve duyuşsal davranışları, çalgı performansını etkilemektedir. Araştırmamızda kullanılan ölçekte bulunan boyutlar öğrencinin çalgı performans yönetimi için plan yapabilmesi ve kendi Öz-düzenlemesini gerçekleştirebilmesi açısından önemlidir. Öğrencinin Kariyer Yönetimi boyutu ile kariyer planlaması ve çalgı çalışmalarını planlaması, Zaman Yönetimi boyutu ile çalışmalarına ayırdığı zaman bakımından kendisini değerlendirmesi, Sahne Yönetimi boyutu ile performans sergilerken heyecan, endişe veya kendini bilmesi, Çalg1 Çalışma Yönetimi boyutu ile çalgı çalışma prensibini oluşturması, Yürütücü biliş ve Motivasyon Yönetimi boyutu ile çalışmalarına odaklanmayı, kendisini çalışmaya teşvik edecek unsurları ve kendisini motive etmenin yollarını bulma hususunda farkındalık oluşturması ve geliştirmesi açısından önemlidir. Bu boyutların çalg1 performans yönetimi öz-yeterlik algısına olan etkileri açısından öğrencinin okul dışında da profesyonel çalışma prensibini kazanabilmesini sağlamaktadır. Yapılan bu araştırmada oluşturulan ve uygulanan ölçek, müzik alanında yapılacak olan öz-yeterlik ile ilgili farklı çalışmalarda kullanılabilir bir veri olarak alana katkı sağlaması açısından önemlidir.

\section{Yöntem}

Bu bölümde, yapılan çalışmanın modeline, araştırmanın çalışma grubuna, kullanılan ölçme aracına ve bu ölçme aracı ile elde edilen verilerin analizinde kullanılan istatistikî tekniklere yer verilmiştir.

\section{Araştırmanın Modeli}

Bu çalışma, mesleki müzik eğitimi alan öğrencilerin çalgı performans yönetimi öz-yeterliklerine yönelik algıların incelemeye yönelik bir ölçek geliştirmeyi hedeflediğinden, temel olarak betimsel nitelikte ve tarama modelini uygun olarak yapılmıştır. Büyüköztürk ve arkadaşlarına (2018) göre "Tarama 
araştırmaları daha çok 'ne, nerede, ne zaman, ne sıklıkta, hangi düzeyde, nasıl' gibi soruların cevaplandırılmasına olanak tanır" (184).

\section{Çalışma Grubu}

Araştırmanın çalışma grubunu, 2018-2019 akademik takvim yılında, Marmara Üniversitesi ve Kocaeli Üniversitesi Müzik Bölümlerinde öğrenim gören toplam 150 öğrenci oluşturmaktadır. Çalışma grubunu oluşturan öğrencilere ait demografik özellikleri aşağıda, Tablo 1 ile Tablo 3 arasında sunulmuştur.

Tablo 1.Öğrencilerin öğrenim gördükleri üniversiteye ilişkin frekans ve yüzde dağılımlan

\begin{tabular}{lll}
\hline Üniversite & N & $\%$ \\
\hline Marmara Üniversitesi & 84 & 56,0 \\
\hline Kocaeli Üniversitesi & 66 & 44,0 \\
\hline Toplam & 150 & 100,0 \\
\hline
\end{tabular}

Çalışmaya katılan öğretmenlerin yarısına yakını, \%56,0 ile Marmara Üniversitesi ve \%44,0’ü Kocaeli Üniversitesinde öğrenim görmektedir.

Tablo 2.Öğrencilerin öğrenim gördükleri sınıfa ilişkin frekans ve yüzde dağılımları

\begin{tabular}{lll}
\hline Sinif & f & \% \\
\hline 1. Sinif & 46 & 30,7 \\
\hline 2. Sinuf & 45 & 30,0 \\
\hline 3. Sinff & 25 & 16,7 \\
\hline 4. Sinff & 17 & 11,3 \\
\hline 5. Sinff & 17 & 11,3 \\
\hline Toplam & 150 & 100,0 \\
\hline
\end{tabular}

Öğrencilerin büyük bir kısmı 1 (\%30,7) ve 2. Sınıflarda (\%30,0) öğrenim görmektedir. 3. Sınıf öğrencileri ise çalışma grubunun $\% 16,7^{\prime}$ sini, 4 ve 5 . S1nıflar ise çalışma grubunun \%11,3'ünü oluşturmaktadır.

Tablo 3.Öğrencilerin cinsiyetine ilişkin frekans ve yüzde dağılımlan

\begin{tabular}{lll}
\hline Cinsiyet & $f$ & $\%$ \\
\hline Bay & 69 & 46,0 \\
\hline Bayan & 81 & 54,0 \\
\hline Toplam & 150 & 100,0 \\
\hline
\end{tabular}

Çalışmaya katılan öğrencilerin \%46,0'sı erkek ve \%54,0'ü bayandır. 
Çalgı Performans Yönetimi Öz-Yeterlik Algısı Ölçeği : Mesleki müzik eğitimi alan öğrencilerin çalgı performans yönetim becerilerine yönelik öz-yeterlik algılarını etkileyen faktörleri ve bu faktörlere ilişkin algı düzeylerini belirlemek üzere araştırmacılar tarafından, Türkiye' de ve yurtdışında yapılan çalışmalar incelenerek ve konunun uzmanlarından alınan görüşler çerçevesinde, beş konu başlığı altında toplam 49 maddeden oluşan, 5'li Likert tipi bir ölçek geliştirilmiştir. Ölçeğin maddeleri/ifadeleri, araştırmaya katılan öğrencilerce, "Kesinlikle katılmıyorum/Bana hiç uymuyor (1)", "Katılmıyorum/Bana uymuyor (2)", “Kararsızım (3)", “Katilıyorum/Bana uyuyor (4)”, ile "Kesinlikle katıllyorum/Bana tamamen uyuyor (5)" derecelendirmelerinden biri seçilerek değerlendirilmektedir. Ölçekte yer alan ifadeler/maddeler arasında olumsuz yüklemli (ters kodlanmış) ifade yoktur ve alınan puanın yüksekliği kişinin o konudaki algısının olumlu olduğunu, düşük ortalama puan ise o alanda algısının olumsuz olduğunu göstermektedir.

\section{Verilerin Analizi}

Mesleki müzik eğitimi alan öğrencilerden, Çalg1 Performans Yönetimi Özyeterlilik Algısı Ölçeği ile toplanan verilerin tümü SPSS 23.0 for Windows programına aktarılmış ve istatistiksel analizler yapılmıştır.

\section{Bulgular}

Çalgı Performans Yönetimi Öz-Yeterlik Algısı Ölçeğinin Faktör Yapısı ve Güvenirlik Analizleri

Araştırmacı tarafından geliştirilen Çalgı Performans Yönetimi Öz-Yeterlik Algısı Ölçeğinin, araştırmaya katılan öğrencilerce tek veya birden çok faktörlü/boyutlu algılanıp algılanmadığı ve bir bütün olarak tutarlı bir şekilde araştırmaya katılan mesleki müzik eğitimi alan öğrencilerin çalgı performans yönetiminde kendi öz-yeterlik becerilerine yönelik algı düzeylerini ölçüp ölçmediğini araştırmak üzere toplanan veriler ile geçerlik ve güvenirlik analizleri kapsamında ölçeğin yapı geçerliğini belirlemek amacıyla açımlayıcı faktör analizi (AFA) ve doğrulayıcı faktör analizi (DFA) uygulanmıştır. Bu temel 
analizler çerçevesinde açımlayıcı faktör analizinde Çalgı Performans Yönetimi Öz-Yeterlik Algısı Ölçeğinin faktör yapılarını tanımlamak üzere önce döndürülmemiş temel bileşenler analizi, daha sonra ise döndürülmüş (varimax) temel bileşenler analizi uygulanmıştır. Açımlayıcı faktör analizi sonucunda belirlenen faktörlerin/boyutların güvenirlilik düzeylerini belirlemek amacıyla ise önce Alpha modeli ile maddeler arası korelâsyona bağlı uyum değerleri (madde toplam korelâsyonları) hesaplanarak Cronbach alfa iç tutarlılık kat sayıları kontrol edilmiştir. Bundan sonra ise her bir maddenin ayırt edicilik düzeyini tespit etmek üzere toplam puana göre belirlenmiş üst \%27 ve alt \%27'lik grupların madde puanları arasındaki farkın anlamlılığı için bağımsız gruplar t-testi kullanılmıştır. Son olarak, bu analizlerin ardından ortaya çıkan Çalg1 Performans Yönetimi Öz-Yeterlik Alg1sı Ölçeğinin faktörel yapısının doğruluğunu test/teyit etmek üzere doğrulayıcı faktör analizi yapilmıştır.

Faktör analizi, araştırmacının, pek çok değişken arasındaki ilişkileri (aynı yapıyı ya da niteliği ölçtüğü düşünülen değişkenleri) daha az sayıda faktör ile açıklamasına yardımcı olmayı amaçlayan bir istatistiksel tekniktir. Büyüköztürk'e göre faktör analizi "Bir faktörleşme ya da ortak faktör adı verilen yeni kavramları (değişkenleri) ortaya çıkarma veya maddelerin faktör yük değerlerini kullanarak kavramların işlevsel tanımlarını elde etme süreci olarak da tanımlanmaktadır" (Büyüköztürk, 2007, s.125). Tavşancıl (2006) da araştırmacının, ölçme aracıyla ölçülen faktörlerin doğası hakkında bir bilgi edinmeye çalıştığı inceleme türünü açımlayıc faktör analizi olarak tanımlamaktadır.

Mesleki müzik eğitimi alan öğrencilerin çalgı performans yönetimi öz-yeterlik becerilerine yönelik algı düzeylerini ölçmeyi amaçlayan 49 maddelik bu ölçeğin tutarlı bir şekilde bu amaca uygun olup olmadığına ilişkin yapılan doğrulayıcı ve açımlayıcı faktör analizi sonuçları aşağıda sırasıyla sunulmuştur.

Tablo 4.Çalgı Performans Yönetimi Öz-Yeterlik Algısı Ölçeğine Yönelik KMO ve Bartlett Testi

\begin{tabular}{lll}
\hline \multicolumn{2}{l}{ Kaiser-Meyer-Olkin Örneklemin Uygunluğu Ölçümü } & 0,885 \\
& \\
\hline Bartlett Küresellik Testi & Yaklaşık Ki-Kare $\left(X^{2}\right)$ & 4286,88 \\
& Serbestlik Derecesi (sd) & 1081 \\
& Anlamlllk (p) & 0,000 \\
\hline
\end{tabular}


Çalgi Performans Yönetimi Öz-Yeterlik Algısı Ölçeği ile toplanan verilerin faktör analizine uygun olup olmadığı Kaiser-Meyer-Olkin (KMO) testi ve Barlett Sphericity testi ile incelemeye tabi tutulmuştur. KMO'nun 0,60'dan yüksek ve Barlett Küresellik testinin anlamlı $(p<.05)$ çıkması durumunda araştırma için toplanan veri setinin açımlayıcı faktör analizine uygun olduğu anlaşılır (Büyüköztürk, 2007, s.126).Barlett küresellik testi bize ayrıca araştırma konusu olan değişkenler arasında yeterli güçlük derecesinde ilişki olup olmadığını (değişkenler arasında en az $p<.05$ düzeyinde anlamlı bir ilişki olduğunu)da göstermektedir (Sipahi, Yurtkoru ve Çinko, 2006:79-80; Leech, Barrett ve Morgan, 2005, s.82).

Çalg1 Performans Yönetimi Öz-Yeterlik Algısı Ölçeği için toplanan verilerin faktör analizine uygunluğu için yapılan Kaiser-Meyer-Olkin (KMO) testi sonucu 0,885 olarak hesaplandığından (0,60'dan büyük olduğundan), Çalg1 Performans Yönetimi Öz-Yeterlik Algısı Ölçeğinin faktör analizine uygun olduğu ve ölçülmesi hedeflenen özelliğin, örneklemin seçildiği evrende çok boyutluluk özelliği taşıdığını göstermektedir [KMO=0,885; $X^{2}=4286,88 ; s d=1081$ ve $p<.001]$. Veri grubu için yapılan Bartlett Küresellik testi sonucu $p<.001$ bulunduğundan, Çalgı Performans Yönetimi Öz-Yeterlik Algısı Ölçeğinin maddeleri arasında anlamlı ve yeterli dercede ilişki olduğu anlaşılmaktadır.

Çalgı Performans Yönetimi Öz-Yeterlik Algısı Ölçeğinin faktör analizine uygunluğu görüldükten sonra veriler açımlayıcı faktör analizine (Exploratory Factor Analysis) tabi tutulmuştur. Faktör analizi kapsamında temel bileşenler analizlerinden Principal Component Analysis, Varimax with Kaiser Normalization teknikleri kullanılmıştır.

Yapılan ilk açımlayıcı faktör analizi sonucu Çalgı Performans Yönetimi Öz-Yeterlik Algısı Ölçeğinin beş boyutlu/faktörlü bir yapıdan oluştuğu ve boyutların toplam varyansın \%58,27'sini açıkladıkları bulunmuştur. Ancak, ölçekte yer alan 1 numaralı maddenin ("01. Kısa vadeli hedefler belirlerim.") üç alt boyutta/faktörde birden ve yüksek faktör yükü aldığı görüldüğgünden (binişik olma özelliği) ölçekten çıkarılmasına karar verilmiştir. Geliştirilen ölçekte yer alan maddelerin yük aldıkları faktörle ilişkisini gösteren faktör yüklerinin en az .30 ile .45 arasında olması önerilmektedir (Leech, Barrett ve Morgan, 2005: 83; Tabachnick ve Fidell, 2013: 611). Ayn maddenin birden fazla 
faktörden yüksek yük alması genelde o maddenin bireylerce iyi anlaşılamadığını gösterdiğinden ya ölçekten çıarılması ya da yeniden yazılmasında fayda vardır (Büyüköztürk, 2012).

İlk faktör analizi sonrası bir madde ölçekten çıarılarak kalan 48 madde ile ikinci defa faktör analizi yapılmış ve Çalgı Performans Yönetimi Öz Yeterlilik Algısı Ölçeğinin yine beş boyuttan meydana geldiği bulunmuştur. İkinci faktör analizi sonrası elde edilen beş boyutlu yapının toplam varyansın \%56,24'ünü açıkladığı görülmüştür. Ancak ikinci faktör analizi sonrası ölçekte yer alan 26 numaralı maddenin ("26.Duruşuma ve dış görünüşüme (kılıkkıyafet) dikkat ederim") .30'dan düşük yük değeri aldığ1 (.102) görüldüğünden bu maddenin de ölçekten çıkarılmasına karar verilerek faktör analizi yenilenmiştir.

01 ve 26 numaralı maddelerin Çalgı Performans Yönetimi Öz-Yeterlik Algısı Ölçeğinden çıkarılması sonrası yapılan üçüncü faktör analizi sonucu, kalan 47 maddenin beş boyutlu bir yapı oluşturduğu (Grafik 1) ve toplam varyansın \%54,30'unu açıkladıkları bulunmuştur. Ölçeğin birinci alt boyutu toplam varyansın $\% 14,85^{\prime}$ ini, ikinci alt boyut $\% 14,67^{\prime}$ sini, üçüncü boyut $\% 11,17$ 'sini, dördüncü boyut $\% 10,44$ 'ünü ve beşinci boyut toplam varyansın \%3,16'sını açıklamaktadır.

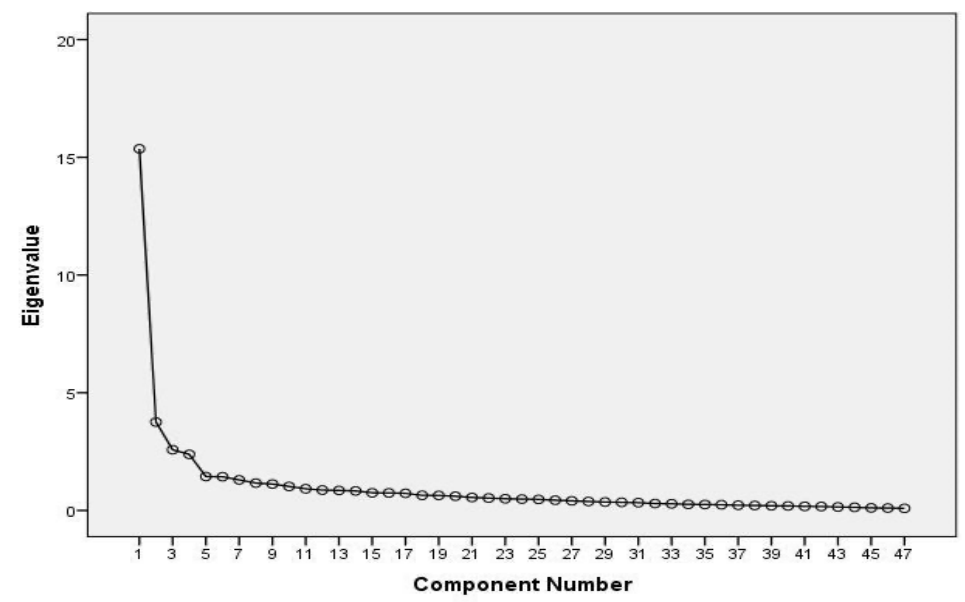

Grafik 1: Çalgı Performans Yönetimi Öz-Yeterlik Algısı Ölçeğinin Faktör Yapılanmasına İlişkin Yamaç Grafiği. 
Grafikten de görüleceği üzere 47 maddeden meydana gelen ölçeğin, 5 . faktörden/boyuttan sonra çizgisinde düşüş başlamış ve diğer faktörlerin ölçeğin açıklıyacılığına katkılarının azaldığı anlaşılmaktadır. Özdeğer grafiği yorumlanırken, grafikteki huzlı düşüşlerin yaşandığı faktör önemli (kesme noktası) sayısı olarak alınır (Büyüköztürk, 2004). Grafik yapılan üçüncü (son) faktör analizini doğrular şekilde 5. noktadan sonra düz olma eğilimi göstermektedir.

Tablo 5.Çalgı Performans Yönetimi Öz-Yeterlik Algısı Ölçeği faktörlerine (boyutlarına) ilişkin açıklanan toplam varyans

\begin{tabular}{|c|c|c|c|c|c|c|}
\hline \multirow{2}{*}{ Bileşen } & \multicolumn{3}{|c|}{ Özdeğer (InitialEigenvalues) } & \multicolumn{3}{|c|}{$\begin{array}{l}\text { Karesi Alınmış Yük Toplamlarının Dön- } \\
\text { dürülmesi }\end{array}$} \\
\hline & Toplam & $\begin{array}{l}\text { Varyansın } \\
\text { Yüzdesi }\end{array}$ & $\begin{array}{l}\text { Yiğılmalı } \\
\text { Yüzde }\end{array}$ & Toplam & $\begin{array}{l}\text { Varyansın } \\
\text { Yüzdesi }\end{array}$ & $\begin{array}{l}\text { Yiğılmalı } \\
\text { Yüzde }\end{array}$ \\
\hline 1 & 15,360 & 32,68 & 32,68 & 6,98 & 14,85 & 14,85 \\
\hline 2 & 3,756 & 7,99 & 40,67 & 6,89 & 14,67 & 29,51 \\
\hline 3 & 2,579 & 5,49 & 46,16 & 5,25 & 11,17 & 40,69 \\
\hline 4 & 2,384 & 5,07 & 51,23 & 4,91 & 10,44 & 51,13 \\
\hline 5 & 1,440 & 3,06 & 54,30 & 1,49 & 3,16 & 54,30 \\
\hline 6 & 0,987 & 3,04 & 57,34 & & & \\
\hline 7 & 0,963 & 2,76 & 60,10 & & & \\
\hline 8 & 0,958 & 2,48 & 62,58 & & & \\
\hline 9 & 0,945 & 2,39 & 64,96 & & & \\
\hline 10 & 0,933 & 2,17 & 67,13 & & & \\
\hline 11 & 0,922 & 1,96 & 69,09 & & & \\
\hline 12 & 0,866 & 1,84 & 70,94 & & & \\
\hline 13 & 0,848 & 1,81 & 72,74 & & & \\
\hline 14 & 0,831 & 1,77 & 74,51 & & & \\
\hline 15 & 0,750 & 1,60 & 76,11 & & & \\
\hline 16 & 0,744 & 1,58 & 77,69 & & & \\
\hline 17 & 0,726 & 1,54 & 79,23 & & & \\
\hline 18 & 0,643 & 1,37 & 80,60 & & & \\
\hline 19 & 0,637 & 1,36 & 81,96 & & & \\
\hline 20 & 0,606 & 1,29 & 83,25 & & & \\
\hline 21 & 0,553 & 1,18 & 84,42 & & & \\
\hline 22 & 0,528 & 1,12 & 85,55 & & & \\
\hline 23 & 0,499 & 1,06 & 86,61 & & & \\
\hline 24 & 0,482 & 1,03 & 87,63 & & & \\
\hline 25 & 0,470 & 1,00 & 88,63 & & & \\
\hline 26 & 0,436 & 0,93 & 89,56 & & & \\
\hline 27 & 0,410 & 0,87 & 90,43 & & & \\
\hline 28 & 0,384 & 0,82 & 91,25 & & & \\
\hline 29 & 0,359 & 0,76 & 92,01 & & & \\
\hline 30 & 0,345 & 0,73 & 92,75 & & & \\
\hline 31 & 0,331 & 0,70 & 93,45 & & & \\
\hline
\end{tabular}




\begin{tabular}{llll}
32 & 0,293 & 0,62 & 94,07 \\
33 & 0,283 & 0,60 & 94,68 \\
34 & 0,261 & 0,56 & 95,23 \\
35 & 0,254 & 0,54 & 95,77 \\
36 & 0,243 & 0,52 & 96,29 \\
37 & 0,221 & 0,47 & 96,76 \\
38 & 0,211 & 0,45 & 97,21 \\
39 & 0,200 & 0,43 & 97,63 \\
40 & 0,190 & 0,41 & 98,04 \\
41 & 0,174 & 0,37 & 98,41 \\
42 & 0,169 & 0,36 & 98,77 \\
43 & 0,148 & 0,31 & 99,08 \\
44 & 0,133 & 0,28 & 99,36 \\
45 & 0,108 & 0,23 & 99,59 \\
46 & 0,102 & 0,22 & 99,81 \\
47 & 0,089 & 0,19 & 100,00 \\
\hline \multicolumn{4}{l}{ Metot: Temel Bileşenler Analizi }
\end{tabular}

Ölçeğin beş boyutlu yapısı, toplam varyasyonun \%54,30'unu açılamaktadır (Tablo 5). Ölçeğin kalan 47 maddesi ile yapılan üçüncü faktör analizi sonrası elde edilen yapıya ait maddelerin aldıkları yük değerleri ise aşağıda, Tablo 6'de sunulmuştur.

Tablo 6.Çalgı Performans Yönetimi Öz-Yeterlik Algısı Ölçeği maddelerine ilişkin döndürülmüş faktör matrisi

\begin{tabular}{|c|c|c|c|c|c|}
\hline \multirow{2}{*}{ Madde } & \multicolumn{5}{|c|}{ Faktör/Boyut } \\
\hline & 1 & 2 & 3 & 4 & 5 \\
\hline Madde 05 & 0,741 & & & & \\
\hline Madde 10 & 0,704 & & & & \\
\hline Madde 03 & 0,704 & & & & \\
\hline Madde 07 & 0,666 & & & & \\
\hline Madde 09 & 0,648 & & & & \\
\hline Madde 04 & 0,630 & & & & \\
\hline Madde 06 & 0,622 & & & & \\
\hline Madde 02 & 0,592 & & & & \\
\hline Madde 08 & 0,491 & & & & \\
\hline Madde 13 & & 0,786 & & & \\
\hline Madde 16 & & 0,706 & & & \\
\hline Madde 12 & & 0,703 & & & \\
\hline Madde 15 & & 0,562 & & & \\
\hline Madde 17 & & 0,555 & & & \\
\hline Madde 11 & & 0,534 & & & \\
\hline Madde 14 & & 0,428 & & & \\
\hline Madde 22 & & & 0,694 & & \\
\hline Madde 19 & & & 0,642 & & \\
\hline Madde 25 & & & 0,609 & & \\
\hline Madde 24 & & & 0,605 & & \\
\hline
\end{tabular}




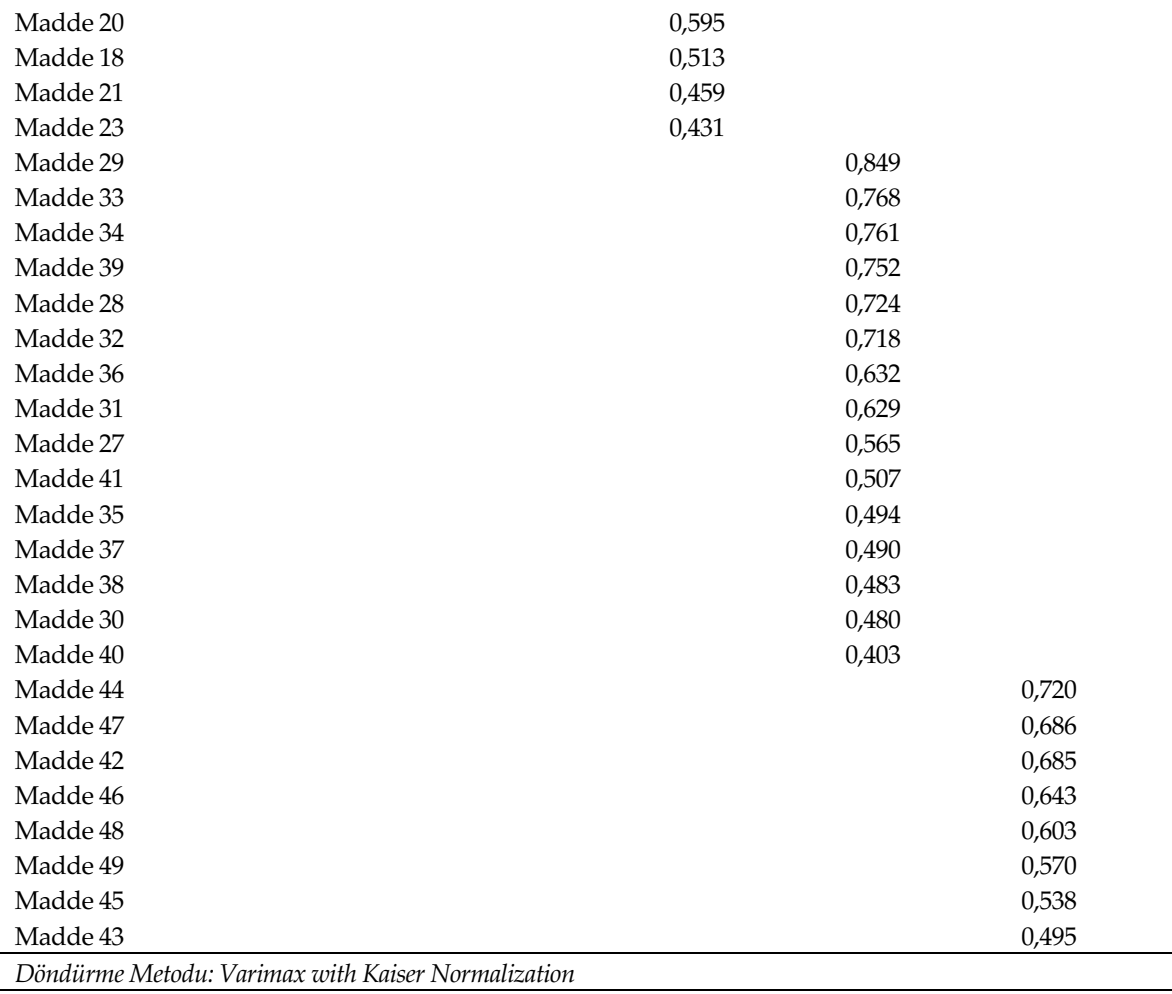

Tablo 6 ' da da görüleceği üzere, iki faktör sekizer madde, iki faktör yedişer madde ve bir faktör 15 maddeden olmak üzere toplamda 47 maddeden oluşan beş faktörlü bir yapı elde edilmiştir. "Faktör yükleri .30'dan küu̧ükse düşük, .40 ve üstü ise iyi düzeyde kabul edilmekte, .50'nin üstünde ise faktör yükleri yüksek kabul edilmektedir" (Leech, Barrett ve Morgan,2005: 83). Çalgı Performans Yönetimi Öz-Yeterlik Algısı Ölçeğinin boyutlarında yer alan maddelerin faktör yükleri ilk faktör için 0,491 ile 0,741 arasında, ikinci faktör için 0,428 ile 0,786 arasında, üçüncü faktör için 0,431 ile 0,694 arasında, dördüncü faktör için 0,403 ile 0,849 arasında ve beşinci faktör için 0,495 ile 720 arasında bulunmuştur.

Faktör analizleri sonrası Çalgı Performans Yönetimi Öz-Yeterlik Algısı Ölçeğinin ve elde edilen faktörlerde yer alan maddelerin güvenirlilik analizleri 
için Alpha modeli ile maddeler arası korelasyona bağlı uyum değerleri hesaplanmıştır (Tablo 7). Alfa $(\alpha)$ katsayısına bağlı olarak ölçek ve alt boyutlarının güvenirliliği aşağıdaki gibi değerlendirilmiştir.

$0.00 \leq \alpha<0.40$ ise ölçek/boyut güvenilir değildir,

$0.40 \leq \alpha<0.60$ ise ölçeğin/boyutun güvenilirliği düşük,

$0.60 \leq \alpha<0.80$ ise ölçek/boyut oldukça güvenilir, ve

$0.80 \leq \alpha<1.00$ ise ölçek/boyut yüksek derecede güvenilirdir (Kalaycı, 2006: s. 405).

Tablo 7.Çalgı Performans Yönetimi Öz-Yeterlik Algısı Ölçeği faktörlerine yönelik güvenirlilik analizi

\begin{tabular}{|c|c|c|c|c|}
\hline Boyut & Madde & $\begin{array}{l}\text { Madde-Toplam } \\
\text { Korelasyonu }\end{array}$ & $\begin{array}{l}\text { Madde Silindiğinde } \\
\text { Cronbach Alfa }(\alpha)\end{array}$ & $\begin{array}{l}\text { Boyuta İlişkin } \\
\text { Cronbach Alfa }(\alpha)\end{array}$ \\
\hline \multirow[t]{9}{*}{ Faktör 1} & Md02 & 0,542 & 0,856 & 0,865 \\
\hline & Md03 & 0,662 & 0,846 & \\
\hline & Md04 & 0,646 & 0,846 & \\
\hline & Md05 & 0,751 & 0,837 & \\
\hline & Md06 & 0,737 & 0,839 & \\
\hline & Md07 & 0,663 & 0,846 & \\
\hline & Md08 & 0,559 & 0,855 & \\
\hline & Md09 & 0,418 & 0,868 & \\
\hline & Md10 & 0,482 & 0,863 & \\
\hline \multirow[t]{7}{*}{ Faktör 2} & Md11 & 0,603 & 0,856 & 0,869 \\
\hline & Md12 & 0,674 & 0,846 & \\
\hline & Md13 & 0,663 & 0,847 & \\
\hline & Md14 & 0,714 & 0,841 & \\
\hline & Md15 & 0,556 & 0,861 & \\
\hline & Md16 & 0,664 & 0,847 & \\
\hline & Md17 & 0,634 & 0,851 & \\
\hline \multirow[t]{8}{*}{ Faktör 3} & Md18 & 0,588 & 0,897 & 0,901 \\
\hline & Md19 & 0,706 & 0,887 & \\
\hline & $\mathrm{Md} 20$ & 0,806 & 0,876 & \\
\hline & Md21 & 0,677 & 0,889 & \\
\hline & $\mathrm{Md} 22$ & 0,722 & 0,886 & \\
\hline & $\mathrm{Md} 23$ & 0,616 & 0,894 & \\
\hline & $\mathrm{Md} 24$ & 0,719 & 0,885 & \\
\hline & $\mathrm{Md} 25$ & 0,671 & 0,890 & \\
\hline \multirow[t]{7}{*}{ Faktör 4} & $\mathrm{Md} 27$ & 0,514 & 0,889 & 0,893 \\
\hline & $\operatorname{Md} 28$ & 0,582 & 0,886 & \\
\hline & $\mathrm{Md} 29$ & 0,704 & 0,880 & \\
\hline & Md30 & 0,572 & 0,886 & \\
\hline & Md31 & 0,579 & 0,886 & \\
\hline & Md32 & 0,669 & 0,882 & \\
\hline & Md33 & 0,519 & 0,889 & \\
\hline
\end{tabular}




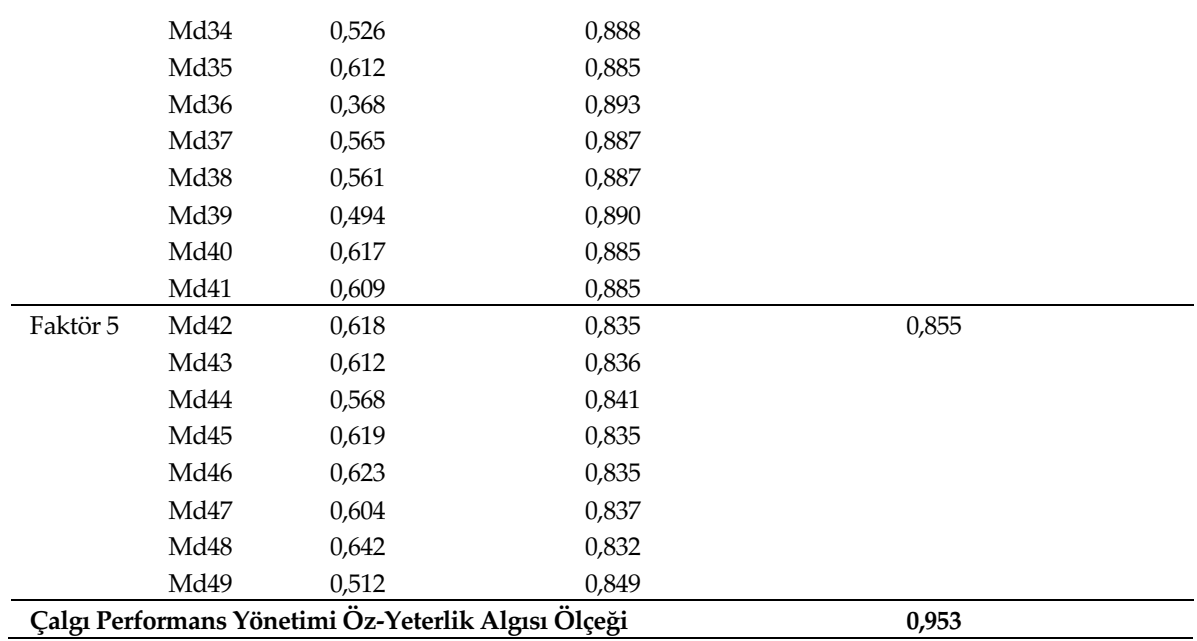

Yapılan 3 faktör analizi sonrası ortaya çıkan yapıya ait birinci faktör için güvenirlik (iç-tutarlılık) katsayısı (Cronbach's Alpha) $\alpha=0,865$; ikinci faktör için 0,869; üçüncü faktör için 0,901; dördüncü faktör için 0,893 ve beşinci faktör için 0,855 olarak bulunmuştur. Bu değerler, Çalg1 Performans Yönetimi Öz-Yeterlik Algısı Ölçeğinin alt boyutlarını oluşturan maddelerin arasında güvenirliğin oldukça yüksek olduğunu göstermektedir. Herhangi bir madde faktörlerden (alt boyuttan) silindiğinde $\alpha$ katsayısının (alt boyutun güvenirlilik katsayısının) yükselmeyeceği görüldügüünden (son sütun) tüm maddelerin bu faktörler altında kalmasına karar verilmiştir.

Çalgi Performans Yönetimi Öz-Yeterlik Algısı Ölçeğinin 47 maddesi (tüm maddeler) birlikte analize dahil edildiğinde ise genel güvenirlik katsayısının 0,953 olduğu bulunmuştur. Bu da Çalgı Performans Yönetimi Öz-Yeterlik Algisı Ölçeğinin bir bütün olarak da kullanılabileceğini ve güvenirlik (iç-tutarll1ık) düzeyinin çok yüksek olduğunu göstermektedir.

Güvenirlik analizi sonrası, Çalgı Performans Yönetimi Öz-Yeterlik Algısı Ölçeğinin kalan 47 maddesinin ayırt edicilik gücünü saptamak üzere bağımsız gruplar t-testi uygulanmıştır. Maddelerin ayırt edicilik düzeylerini belirlemek üzere ölçekten elde edilen ham puanlar büyükten küçüğe doğru sıralandıktan sonra alt $\% 27$ ve üst $\% 27$ 'yi oluşturan grupların puan ortalamalar1nın " $t$ " değerleri hesaplanarak maddelerin ayırt edicilik güçleri elde edilmiştir (Tablo 8). 
Tablo 8. Çalgı Performans Yönetimi Öz-Yeterlik Algısı Ölçeği maddelerinin ayırt ediciliklerine ilişkin t testi

\begin{tabular}{|c|c|c|c|c|c|c|c|}
\hline \multirow{2}{*}{ Madde } & \multirow{2}{*}{ Alt-Üst \%27 } & \multicolumn{2}{|c|}{ Betimsel İst. } & \multirow[b]{2}{*}{ Ss } & \multicolumn{2}{|l|}{$t$-test } & \multirow[b]{2}{*}{$P$} \\
\hline & & $n$ & $\bar{X}$ & & $t$ & $s d$ & \\
\hline \multirow[t]{2}{*}{ Md02 } & Alt \%27 & 41 & 3,37 & 1,18 & $-6,69$ & 80 & $0,000^{* * *}$ \\
\hline & Üst \%27 & 41 & 4,71 & 0,51 & & & \\
\hline \multirow[t]{2}{*}{ Md03 } & Alt \%27 & 41 & 3,34 & 0,94 & $-8,01$ & 80 & $0,000^{* * * *}$ \\
\hline & Üst \%27 & 41 & 4,71 & 0,56 & & & \\
\hline \multirow[t]{2}{*}{ Md04 } & Alt \%27 & 41 & 3,05 & 1,09 & $-8,97$ & 80 & $0,000^{* * * *}$ \\
\hline & Üst \%27 & 41 & 4,76 & 0,54 & & & \\
\hline \multirow[t]{2}{*}{ Md05 } & Alt \%27 & 41 & 3,07 & 0,96 & $-9,24$ & 80 & $0,000^{* * *}$ \\
\hline & Üst \%27 & 41 & 4,71 & 0,60 & & & \\
\hline \multirow[t]{2}{*}{ Md06 } & Alt \%27 & 41 & 3,24 & 0,97 & $-9,53$ & 80 & $0,000^{* * * *}$ \\
\hline & Üst \%27 & 41 & 4,80 & 0,40 & & & \\
\hline \multirow[t]{2}{*}{ Md07 } & Alt \%27 & 41 & 3,49 & 1,00 & $-5,79$ & 80 & $0,000^{* * * *}$ \\
\hline & Üst \%27 & 41 & 4,56 & 0,63 & & & \\
\hline \multirow[t]{2}{*}{ Md08 } & Alt \%27 & 41 & 3,15 & 1,15 & $-7,38$ & 80 & $0,000^{* * *}$ \\
\hline & Üst \%27 & 41 & 4,63 & 0,58 & & & \\
\hline \multirow[t]{2}{*}{ Md09 } & Alt \%27 & 41 & 2,61 & 1,16 & $-6,16$ & 80 & $0,000^{* * *}$ \\
\hline & Üst \%27 & 41 & 4,05 & 0,95 & & & \\
\hline \multirow[t]{2}{*}{ Md10 } & Alt \%27 & 41 & 3,07 & 1,13 & $-5,64$ & 80 & $0,000^{* * *}$ \\
\hline & Üst \%27 & 41 & 4,41 & 1,02 & & & \\
\hline \multirow[t]{2}{*}{ Md11 } & Alt $\% 27$ & 41 & 2,46 & 0,84 & $-8,78$ & 80 & $0,000^{* * * *}$ \\
\hline & Üst \%27 & 41 & 4,12 & 0,87 & & & \\
\hline \multirow[t]{2}{*}{ Md12 } & Alt \%27 & 41 & 2,83 & 0,95 & $-9,01$ & 80 & $0,000^{* * * *}$ \\
\hline & Üst \%27 & 41 & 4,46 & 0,67 & & & \\
\hline \multirow[t]{2}{*}{ Md13 } & Alt \%27 & 41 & 2,37 & 0,86 & $-9,11$ & 80 & $0,000^{* * * *}$ \\
\hline & Üst \%27 & 41 & 4,15 & 0,91 & & & \\
\hline \multirow[t]{2}{*}{ Md14 } & Alt \%27 & 41 & 2,73 & 0,95 & $-10,11$ & 80 & $0,000^{* * * *}$ \\
\hline & Üst \%27 & 41 & 4,54 & 0,64 & & & \\
\hline \multirow{2}{*}{ Md15 } & Alt \%27 & 41 & 2,78 & 0,99 & $-8,39$ & 80 & $0,000^{* * *}$ \\
\hline & Üst \%27 & 41 & 4,37 & 0,70 & & & \\
\hline \multirow[t]{2}{*}{ Md16 } & Alt \%27 & 41 & 2,41 & 0,89 & $-9,05$ & 80 & $0,000^{* * * *}$ \\
\hline & Üst \%27 & 41 & 4,12 & 0,81 & & & \\
\hline Md17 & Alt \%27 & 41 & 2,61 & 0,83 & $-8,17$ & 80 & $0,000^{* * *}$ \\
\hline & Üst \%27 & 41 & 4,12 & 0,84 & & & \\
\hline Md18 & Alt \%27 & 41 & 3,20 & 0,84 & $-7,81$ & 80 & $0,000^{* * * *}$ \\
\hline & Üst $\% 27$ & 41 & 4,51 & 0,68 & & & \\
\hline Md19 & Alt $\% 27$ & 41 & 3,02 & 0,91 & $-7,62$ & 80 & $0,000^{* * * *}$ \\
\hline & Üst $\% 27$ & 41 & 4,39 & 0,70 & & & \\
\hline Md20 & Alt \%27 & 41 & 2,76 & 1,09 & $-7,23$ & 80 & $0,000^{* * *}$ \\
\hline & Üst \%27 & 41 & 4,32 & 0,85 & & & \\
\hline Md21 & Alt \%27 & 41 & 2,98 & 1,13 & $-5,54$ & 80 & $0,000^{* * * *}$ \\
\hline & Üst \%27 & 41 & 4,20 & 0,84 & & & \\
\hline $\operatorname{Md} 22$ & Alt \%27 & 41 & 3,22 & 1,04 & $-7,05$ & 80 & $0,000^{* * *}$ \\
\hline & Üst \%27 & 41 & 4,54 & 0,60 & & & \\
\hline $\mathrm{Md} 23$ & Alt \%27 & 41 & 3,34 & 1,06 & $-6,72$ & 80 & $0,000^{* * * *}$ \\
\hline & Üst \%27 & 41 & 4,63 & 0,62 & & & \\
\hline Md24 & Alt \%27 & 41 & 2,95 & 1,02 & $-7,20$ & 80 & $0,000^{* * *}$ \\
\hline & Üst \%27 & 41 & 4,41 & 0,81 & & & \\
\hline
\end{tabular}


Çalg1 Performans Yönetimi Öz-Yeterlik Algısı Ölçeği Geliştirme Çalışması

\begin{tabular}{|c|c|c|c|c|c|c|c|}
\hline \multirow[t]{2}{*}{$\mathrm{Md} 25$} & Alt $\% 27$ & 41 & 3,07 & 0,91 & $-7,59$ & 80 & $0,000^{* * * *}$ \\
\hline & Üst \%27 & 41 & 4,49 & 0,78 & & & \\
\hline \multirow[t]{2}{*}{$\mathrm{Md} 27$} & Alt \%27 & 41 & 2,20 & 0,93 & $-5,94$ & 80 & $0,000^{* * *}$ \\
\hline & Üst \%27 & 41 & 3,51 & 1,08 & & & \\
\hline \multirow[t]{2}{*}{$\mathrm{Md} 28$} & Alt \%27 & 41 & 2,66 & 0,97 & $-7,00$ & 80 & $0,000^{* * *}$ \\
\hline & Üst \%27 & 41 & 4,12 & 0,93 & & & \\
\hline \multirow[t]{2}{*}{ Md29 } & Alt \%27 & 41 & 2,39 & 0,92 & $-8,60$ & 80 & $0,000^{* * * *}$ \\
\hline & Üst \%27 & 41 & 4,20 & 0,98 & & & \\
\hline \multirow[t]{2}{*}{ Md30 } & Alt $\% 27$ & 41 & 3,27 & 1,03 & $-6,60$ & 80 & $0,000^{* * *}$ \\
\hline & Üst \%27 & 41 & 4,51 & 0,64 & & & \\
\hline \multirow[t]{2}{*}{ Md31 } & Alt \%27 & 41 & 2,71 & 0,96 & $-7,57$ & 80 & $0,000^{* * *}$ \\
\hline & Üst \%27 & 41 & 4,22 & 0,85 & & & \\
\hline \multirow[t]{2}{*}{ Md32 } & Alt \%27 & 41 & 2,37 & 0,97 & $-7,77$ & 80 & $0,000^{* * * *}$ \\
\hline & Üst \%27 & 41 & 3,98 & 0,91 & & & \\
\hline \multirow[t]{2}{*}{ Md33 } & Alt \%27 & 41 & 2,88 & 1,14 & $-5,37$ & 80 & $0,000^{* * * *}$ \\
\hline & Üst \%27 & 41 & 4,15 & 0,99 & & & \\
\hline \multirow[t]{2}{*}{ Md34 } & Alt \%27 & 41 & 3,12 & 0,93 & $-6,62$ & 80 & $0,000^{* * * *}$ \\
\hline & Üst \%27 & 41 & 4,34 & 0,73 & & & \\
\hline \multirow[t]{2}{*}{ Md35 } & Alt \%27 & 41 & 2,66 & 1,09 & $-7,60$ & 80 & $0,000^{* * * *}$ \\
\hline & Üst $\% 27$ & 41 & 4,34 & 0,91 & & & \\
\hline \multirow[t]{2}{*}{ Md36 } & Alt $\% 27$ & 41 & 3,61 & 0,97 & $-4,57$ & 80 & $0,000^{* * * *}$ \\
\hline & Üst \%27 & 41 & 4,51 & 0,81 & & & \\
\hline \multirow[t]{2}{*}{ Md37 } & Alt $\% 27$ & 41 & 3,27 & 0,84 & $-7,26$ & 80 & $0,000^{* * *}$ \\
\hline & Üst \%27 & 41 & 4,49 & 0,68 & & & \\
\hline \multirow[t]{2}{*}{ Md38 } & Alt \%27 & 41 & 2,85 & 0,91 & $-8,01$ & 80 & $0,000^{* * * *}$ \\
\hline & Üst \%27 & 41 & 4,27 & 0,67 & & & \\
\hline \multirow[t]{2}{*}{ Md39 } & Alt \%27 & 41 & 2,76 & 1,22 & $-5,69$ & 80 & $0,000^{* * * *}$ \\
\hline & Üst \%27 & 41 & 4,10 & 0,89 & & & \\
\hline \multirow[t]{2}{*}{$\mathrm{Md} 40$} & Alt \%27 & 41 & 2,83 & 0,92 & $-6,01$ & 80 & $0,000^{* * * *}$ \\
\hline & Üst \%27 & 41 & 4,02 & 0,88 & & & \\
\hline \multirow[t]{2}{*}{ Md41 } & Alt \%27 & 41 & 2,83 & 1,00 & $-6,45$ & 80 & $0,000^{* * * *}$ \\
\hline & Üst \%27 & 41 & 4,10 & 0,77 & & & \\
\hline \multirow[t]{2}{*}{$\mathrm{Md} 42$} & Alt \%27 & 41 & 3,10 & 0,89 & $-8,43$ & 80 & $0,000^{* * *}$ \\
\hline & Üst \%27 & 41 & 4,54 & 0,64 & & & \\
\hline \multirow[t]{2}{*}{$\mathrm{Md} 43$} & Alt \%27 & 41 & 3,24 & 0,94 & $-6,43$ & 80 & $0,000^{* * *}$ \\
\hline & Üst \%27 & 41 & 4,51 & 0,84 & & & \\
\hline \multirow[t]{2}{*}{ Md44 } & Alt $\% 27$ & 41 & 3,32 & 0,91 & $-7,35$ & 80 & $0,000^{* * *}$ \\
\hline & Üst \%27 & 41 & 4,59 & 0,63 & & & \\
\hline \multirow[t]{2}{*}{$\mathrm{Md} 45$} & Alt \%27 & 41 & 3,29 & 1,10 & $-6,21$ & 80 & $0,000^{* * * *}$ \\
\hline & Üst $\% 27$ & 41 & 4,49 & 0,55 & & & \\
\hline \multirow[t]{2}{*}{ Md46 } & Alt \%27 & 41 & 3,15 & 1,06 & $-6,37$ & 80 & $0,000^{* * * *}$ \\
\hline & Üst \%27 & 41 & 4,41 & 0,71 & & & \\
\hline $\mathrm{Md} 47$ & Alt $\% 27$ & 41 & 2,27 & 1,03 & $-7,56$ & 80 & $0,000^{* * *}$ \\
\hline & Üst \%27 & 41 & 3,88 & 0,90 & & & \\
\hline $\mathrm{Md} 48$ & Alt \%27 & 41 & 2,59 & 1,12 & $-8,86$ & 80 & $0,000^{* * *}$ \\
\hline & Üst \%27 & 41 & 4,41 & 0,71 & & & \\
\hline $\operatorname{Md} 49$ & Alt \%27 & 41 & 3,05 & 1,02 & $-6,12$ & 80 & $0,000^{* * *}$ \\
\hline & Üst \%27 & 41 & 4,34 & 0,88 & & & \\
\hline
\end{tabular}


Tablo 8'den görüleceği üzere, faktör ve madde analizleri sonrası Çalg1 Performans Yönetimi Öz-Yeterlik Algısı Ölçeğinin kalan 47 maddesine ilişkin yapılan ayırt edicilik testi, tüm maddelerin $p<.001$ düzeyinde anlamlı bir şekilde ayırt edici özelliği taşıdığını göstermektedir.

Ayırt edicilik testi sonrası ölçeğin faktörlerinde yer alan maddelerin ortak özellikleri ve yapılan kuramsal çalışma dikkate alınarak; Faktör 1'e, 'Kariyer yönetimi', Faktör 2'ye, 'Zaman yönetimi', Faktör 3'e, 'Sahne yönetimi', Faktör 4'e 'Çalgi çalışma yönetimi' ve Faktör 5'e 'Yürütücü biliş ve motivasyon yönetimi', adlarının verilmesi uygun bulunmuştur.

Son olarak, Çalgı Performans Yönetimi Öz-Yeterlik Alg1sı Ölçeğinin ölçek geneli ile beş alt boyutu/faktörü arasında anlamlı bir ilişki olup olmadığı Pearson momentler çarpımı korelasyonu katsayıları incelenerek araştırılmıştır (Tablo 9). Ölçek ve alt boyutları ile alt boyutların kendi aralarında bulunan ilişkiler (korelasyon katsayıları) aşağıdaki kriterlere göre değerlendirilmiştir;

\begin{tabular}{lll}
\hline $\boldsymbol{R}$ & 苂işki \\
\cline { 3 - 3 } & Yok \\
$0,10-0,30$ & Zaylf \\
$0,30-0,50$ & Orta \\
$0,50-0,70$ & Güçlü \\
$0,70-1,00$ & Çok Güçlü (Jawlik, 2016, s.132) \\
\hline
\end{tabular}

Tablo 9.Çalgı Performans Yönetimi Öz-Yeterlik Algısı Ölçeğinin geneli ile alt boyutları arasindaki korelasyon katsayılarn

\begin{tabular}{|c|c|c|c|c|c|c|c|}
\hline Faktör/Boyut & & $\begin{array}{l}\text { Kariyer } \\
\text { y. }\end{array}$ & Zaman y. & $\begin{array}{l}\text { Sahne } \\
\text { y. }\end{array}$ & $\begin{array}{l}\text { Çalg1 } \\
\text { çalışma y. }\end{array}$ & $\begin{array}{l}\text { Yürütücü biliş } \\
\text { ve motivasyon y. }\end{array}$ & Ölçek \\
\hline \multirow[t]{2}{*}{ Kariyer yönetimi } & $r$ & 1 & ,699*** & $421 * * *$ &, $715^{* * *}$ &, $505^{* * *}$ &, $832^{* * *}$ \\
\hline & $p$ & & 0,000 & 0,000 & 0,000 & 0,000 & 0,000 \\
\hline \multirow[t]{2}{*}{ Zaman yönetimi } & $\mathrm{r}$ & & 1 &, $362^{2 * * *}$ &, $766^{* * *}$ &, $508^{* * *}$ &, $836^{* * *}$ \\
\hline & $\mathrm{p}$ & & & 0,000 & 0,000 & 0,000 & 0,000 \\
\hline \multirow[t]{2}{*}{ Sahne yönetimi } & $r$ & & & 1 &, $410^{* * *}$ &, $451^{* * *}$ &, $677^{* * *}$ \\
\hline & $p$ & & & & 0,000 & 0,000 & 0,000 \\
\hline \multirow{2}{*}{$\begin{array}{l}\text { Çalgı çalışma yö- } \\
\text { netimi }\end{array}$} & $r$ & & & & 1 &, $631^{* * *}$ &, $873^{* * *}$ \\
\hline & $p$ & & & & & 0,000 & 0,000 \\
\hline \multirow{2}{*}{$\begin{array}{l}\text { Yürütücü bilişve } \\
\text { motivasyon yöne- } \\
\text { timi }\end{array}$} & $r$ & & & & & 1 &, $774^{* * *}$ \\
\hline & $p$ & & & & & & 0,000 \\
\hline Çalg1 Performans & $r$ & & & & & & 1 \\
\hline $\begin{array}{l}\text { Yönetimi Öz-Ye- } \\
\text { terlik Algısı Ölçeği }\end{array}$ & $p$ & & & & & & \\
\hline$* * *<<, 001$ & & & & & & & \\
\hline
\end{tabular}


Çalgı Performans Yönetimi Öz-Yeterlik Algısı Ölçeğinin geneli ile alt boyutlarının tümü arasında pozitif yönde ve güçlü ile çok güçlü düzeyde anlamlı bir ilişki vardır ( $r$ Ölçek*Kariyer yönetimi $=0,832$; $r$ Ölçek*Zaman yönetimi $=0,836$; $r$ Ölçek*Sahne yönetimi $=0,677$; $r$ Ölçek"Çalgı çalş̧ma yönetimi $=0,873$ ve $r$ Ölçek"Yürütücü biliş ve motivasyon yönetimi $=0,774$; $p<.001)$. Boyutlar/faktörler arası korelasyon katsayıları da 0,362 ile 0,766 arasında değişmekte olup, pozitif yönde anlamlı ilişkiler olduğu bulunmuştur. Özetle, ölçek ile tüm alt boyutlar arasında ve tüm alt boyutların kendi arasında istatistiksel olarak, .001 düzeyinde anlamlı pozitif ve orta derece ile çok güçlü derecede ilişkiler olduğu bulunmuştur.

\section{Çalgı Performans Yönetimi Öz-Yeterlik Algısı Ölçeğine İlişkin Doğrulayıcı Faktör Analizi}

Çalışma ile elde edilen veriler üzerinde uygulanan açıklayıcı faktör analizi sonrası saptanan faktörler/boyutların teorik (uyum indekslerine) kriterlere uygunluğunu test etmek üzere doğrulayıcı faktör analizi yapılarak elde edilen uyum değerleri incelenmiştir.

“Doğrulayıcı faktör analizi, açıklayıcı faktör analizi ile belirlenen faktörlerin hipotez ile belirlenen faktör yapılarına uygunluğunu test etmek üzere yararlanılan faktör analizidir" (Karagöz, 2017, s.486). Büyüköztürk (2004) de doğrulayıc faktör analizini, kurgu (hipotez) ile gerçek veriler arasındaki uyumun (model uyumunun) testi olarak tanımlamaktadır. "Doğrulayıcı faktör analizi kuramsal bir temele dayanarak çeşitli değişkenlerden oluşturulan faktörlerin gerçek verilerle ne derece uyum gösterdiğini değerlendirmeye yönelik yapılan bir analiz olduğundan, toplanan verilerin kurgulanmış yapıya ne derece uygun olduğunu gösterir (Büyüköztürk, 2004, s.128).

Test edilen kuramsal modelin yeterliliği için pek çok uyum indeksi kullanılmaktadır. Bu çalışmada doğrulayıcı faktör analizi için Ki-kare uyum testi $\left(X^{2}\right)$, Uygunluk İndeksi (GFI), Düzeltilmiş Uygunluk İndeksi (AGFI), Yaklaşık Hataların Ortalama Karekökü (RMSEA), Hataların Karekökü (RMR), Normlaştırılmış Uyum İndeksi (NFI) ve Göreceli Uygunluk İndeksi (CFI) uyum indeksleri incelenmiştir. EFA ile belirlenen Çalgı Performans Yönetimi Öz-Yeterlik Algısı Ölçeği ve alt boyutlarına ilişkin model, ikinci düzey DFA ile test edilmiştir (Tablo 10 ve Grafik 2). 
Beş boyutlu/faktörlü Çalgı Performans Yönetimi Öz-Yeterlik Algısı Ölçeği için yapılan doğrulayıcı faktör analizinin sonuçları aşağıdaki uyum indeksi ölçülerine uygun olarak değerlendirilmiştir.

\section{DFA İndeks Ölcüttleri}

\begin{tabular}{|c|c|c|}
\hline $\mathrm{X}^{2} / \mathrm{sd}$ & & $\leq 3$ \\
\hline RMR & & $\leq 0,1$ \\
\hline RMSEA & $\leq 0,08$ & \\
\hline AGFI & & $\geq 0,80$ \\
\hline GFI, CFI, NFI & & $\geq 0,90$ (Hair ve diğerleri, 2010, s.94). \\
\hline
\end{tabular}

İlk olarak, Çalgı Performans Yönetimi Öz-Yeterlik Algısı Ölçeğinin geneli ile birlikte beş boyutlu (ikinci düzey) modeller için $\mathrm{X}^{2} / \mathrm{sd}$ değerinin $0 \leq \mathrm{X} 2 / \mathrm{sd}$ $\leq 3$ sınırları içinde çıtığı görülmüsstür. Bu sonuç, kuramsal modelin uyumlu olduğuna ilişkin en önemli kanıtlarından biridir ( $X^{2} /$ sd Beş Boyut + Ölçeğin geneli=1,82) (Tablo 10). $X^{2} /$ sd oranının 3 'ün altında olması sinanan modellerin uyumlu olduğuna ilişkin önemli bir ölçüttür (Şimşek,2007).

Tablo 10.Çalgı Performans Yönetimi Öz-Yeterlik Algısı Ölçeğine ilişkin doğrulayıcı faktör analizi

\begin{tabular}{llllllllll}
\hline \multirow{2}{*}{\begin{tabular}{l} 
Model \\
\cline { 2 - 10 } Ölçek + 5 Boyut
\end{tabular}} & $X^{2}$ & $s d$ & $X^{2} /$ sd & GFI & AGFI & RMSEA & RMR & NFI & CFI \\
\cline { 2 - 9 } & 1873,71 & 1029 & 1,82 & 0,932 & 0,889 & 0,074 & 0,086 & 0,917 & 0,966 \\
\hline
\end{tabular}

RMSEA'nın 0,050' den küçük olması 'mükemmel', 0,080'den küçük olması 'iyi' ve 0,10' dan küçük olması ise 'zayıf' uyuma işaret etmektedir (Jöreskog, 1979). Bu durumda test edilen modelin uyum düzeyinin iyi olduğu anlaşılmaktadır (RMSEA=0,074). Diğer uyum değerlerinin de sınırlar içinde olduğu görüldüğünden daha önce açıklayıcı faktör analizi ile oluşturulan modelin doğrulayıcı faktör analizi ile de teyit edildiği gözlemlenmektedir. Sonuç olarak, Çalgı Performans Yönetimi Öz-Yeterlik Algısı Ölçeğinin 47 madde ve beş alt boyuttan meydana geldiği, doğrulayıc faktör analizi uyum kriterleri ile de teyit edilmiş ve bu modelin kuramsal ve istatistiksel açıdan uygun olduğu anlaşılmaktadır. Doğrulayıcı faktör analizi ile bulunan ölçeğin boyutları arasindaki korelasyon katsayıları $(0,49$ ile 0,96$)$ ve faktör yüklerinin ( 0,50 ile 0,89$)$ de oluşturulan modelin uygunluğunu doğruladığı görülmektedir (Grafik 2). 


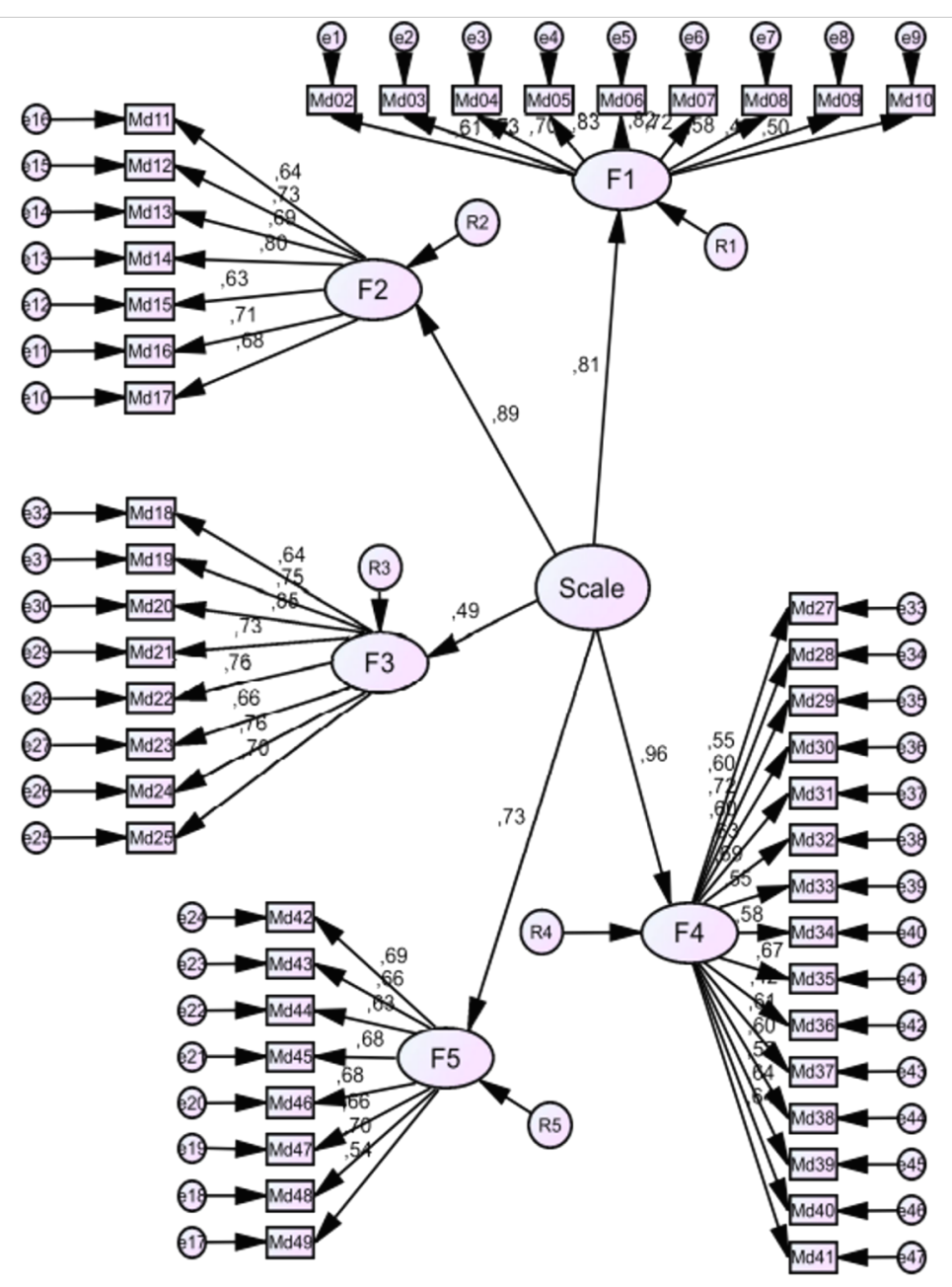

Grafik 2.Çalgı Performans Yönetimi Öz-Yeterlik Algısı Ölçeğine İlişkin 2. Düzey (Ölçek + Boyutlar) Doğrulayıcı Faktör Analizi.

\section{Sonuç}

Bu çalışmada, Çalgı Performans Yönetimi Öz-Yeterlik Algısı Ölçeği geliştirilmiştir. Bu amaç ile toplamda 47 maddeden oluşan bir ölçme aracı oluşturulmuştur. Ölçeğin Cronbach Alfa katsayısı 0.953 olarak hesaplanmıştır. Ölçek, 
5'li likert tipi bir ölçek olup, puanlamalar 1 ile 5 puan arası yapılmıştır. Çalgı Performans Yönetimi Öz-Yeterlik Algısı Ölçeği 5 alt boyuttan oluşmaktadır. Ölçeğin alt ölçeklerini oluştururken Kariyer Yönetimi, Zaman Yönetimi, Sahne Yönetimi, Çalg1 Çalışma Yönetimi ve Yürütücü biliş ve Motivasyon Yönetimi boyutlarından yararlanılmıştır. Araştırmada, Kariyer Yönetimi alt ölçeğinde 9, Zaman Yönetimi alt ölçeğinde 7, Sahne yönetimi alt ölçeğinde 8, Çalgı Çalışma Yönetimi alt ölçeğinde 15 ve Yürütücü biliş ve Motivasyon alt ölçeğinde 8 madde olarak toplamda 47 madde yer almaktadır. Açıklayıcı faktör analizi sonuçlarına göre elde edilen 5 faktörün açıklanan toplam varyansa katkısı \%58,27 oranında saptanmıştır. Her bir faktörün Cronbach Alpha güvenirlik katsayıları incelendiğinde, katsayıların 0.677 ile 0.873 arasında değiştiği görülmektedir. Ölçekte tüm alt boyutlar arasında ve tüm alt boyutların kendi arasında istatistiksel olarak, .001 düzeyinde anlamlı pozitif ve orta derece ile çok güçlü derecede ilişkiler olduğu saptanmıştır. 


\section{EXTENDED ABSTRACT}

\section{A Scale Development Study on the Perception of Self-Efficiency in Instrument Performance Management \\ Ümit Can Kubilay - Özlem Yorulmaz Birdal Kocaeli Üniversity}

Instrument training is a process which includes learning various methods and techniques to play a particular instrument. This field necessitates a great study discipline. At the end of instrument studies, students are to present the output of what they have learned by performing with their instruments. Performing with an instrument is rather challenging and $I t$ is necessary to overcome various difficulties by making effort. These problems include technical deficiencies, and wrong sounds and nuances may disrupt the flow of the work. Stage acoustics and lack of materials make performing difficult. Works of art that are not suitable for the level of the student may well result in the performance not to be carried out at the desired level. In order to overcome all these above-mentioned problems, one needs to control their mood and motivation. In order to achieve a good performance, the studies should be planned in line with the objectives. In this process, which also develops the vision and skills of the individual, performance management successfully reveals the goals to be achieved. As in this study, the plans made in order to reach the desired goals and objectives in Instrument Performance Management can be organized within the framework of various dimensions such as Career Management, Time Management, Stage Management, Executive Cognition and Motivation.

Career management can be defined as the determination of appropriate goals in line with the interests and abilities of the individual in his professional life. If the individual makes plans by using the time correctly, it is possible for him to reach his goals in a shorter term. Time Management includes the implementation of plans in order of priority so that the desired performance can be achieved at the desired time. There are factors that negatively affect the working time. Continuous interruption of work by visitors, telep- 
hone or noise negatively affects time management. In order not to be influenced by these factors, instrument studies should also be planned and managed. Instrument Study Management is the whole of technical, environmental, temporal and physical planning to be applied to the preparation process of the performance to be exhibited in line with the objectives. Factors such as the arrangement of the working environment, the effective and correct use of materials, and the application of warm-up and relaxation movements to prepare the body for work ensure proper instrument study management. In Stage Management, the individual must have a good command of the area where the performance will take place. Proper use and acoustic distribution of the stage will pave the way for the performance to look and sound better. It is possible for the individual to worry and panic in front of the audience on stage. However, as the level of anxiety increases, the psychological changes experienced can negatively affect performance. The person should be aware of all these situations and control his mood and motivation. This can be achieved by managing executive cognition and motivation. Executive cognition is the individual's awareness of what he can learn and how. In this way, the individual can organize his studies under his own supervision and evaluate them at the end. Motivation of the individual as a result of various needs can ensure the realization of the intended performance. The support of the parents and the teacher in the field that the student will choose in line with his abilities increase the motivation of the student for his performance. By making plans in all these areas, the individual can develop his/her self-efficacy perception by making his/her self-regulation and self-evaluation.

The concept of self-efficacy was first introduced by Albert Bandura and it refers to an individual's belief in his own abilities. The higher the individual's self-efficacy perception is, the more challenging goals he sets for himself. In this difficult situation, people with high self-efficacy can overcome this difficulty with studying more. People with low self-efficacy, on the other hand, may prefer to quit and give up when they have difficulty in achieving the goals they have set for themselves, rather than going over these difficulties and working on them. There are four main sources that feed into the development of self-efficacy. The first source is direct experiences. The success and failure of the person in their past experiences also affect their self-efficacy perception on their future performance. In indirect experiences, 
which are considered as the second source of self-efficacy, a model that one witnesses and sees close to his/her own situation compares his/her experiences to his/her own future experiences. In verbal persuasion, which is the third source of self-efficacy, the effect of advice, good words, and encouraging actions that increase the motivation of the individual provide the development of self-efficacy perception. When the psychological state is taken into consideration, which is the last source of self-efficacy, the stress, fatigue, fear and physiological disturbances experienced by the individual as a result of certain reasons come to the fore. The fact that these psychological conditions experienced by the individual create a restrictive and compelling situation for the individual's movements may negatively affect the performance to be exhibited.

In this study conducted in the field of education, the necessity of a measurement tool to reveal the instrument performance management self-efficacy perceptions of the music department students was felt and the lack of comprehensive scales in this area was determined as the problem of this study. The objective of this current study is to develop a valid and reliable scale that can reveal the perceptions of students at vocational music education about their self-efficacy skills in instrument performance management. The scale created and applied in this research is important in terms of contributing to the field as a usable data in different studies on self-efficacy in the field of music.

Since this current study aims to develop a scale to examine the perceptions of students receiving vocational music education about self-efficacy in instrument performance management, it was basically conducted in a descriptive nature and in accordance with the survey model. The study group of the research consists of a total of 150 students studying at Marmara University and Kocaeli University Music Departments in 2018-2019 academic year. All the data collected with the Scale of Self-Efficacy Perception in Instrument Performance Management from the students receiving professional music education were transferred to the SPSS 23.0 for Windows and statistical analyzes were carried out.

The Scale of Self-Efficacy Perception in Instrument Performance Management was developed as a 5-point Likert type scale consisting of 49 items. Exploratory factor analysis (EFA) and confirmatory factor analysis (CFA) were applied to determine the construct validity of the scale within the 
scope of validity and reliability analyzes from the data collected to investigate whether the students receiving professional music education measure their self-efficacy skills in instrument performance management. In order to determine the reliability level of the factors determined as a result of the exploratory factor analysis, the correlation values between the items were calculated with the Alpha model and the Cronbach Alpha internal consistency coefficients were checked. After all these analyzes, confirmatory factor analysis was performed to test the accuracy of the factorial structure of the scale. The Kaiser-Meyer-Olkin test and the Barlett Sphericity test were used to ensure that the data collected with the scale were suitable for factor analysis. As a result of these tests, it is revealed that the scale is suitable for factor analysis and that the items are significantly and adequately related. As a result of the factor analysis, it was deemed appropriate to remove 2 items from the 49-item scale. The reliability and internal consistency of the remaining 47 items of the scale were found to be quite high. After the factor and discrimination tests were applied, it was observed that it has a significant distinctive feature at the $p<.001$ level of the Scale of Self-Efficacy Perception in Instrument Performance Management. There is a positive and very strong significant relationship between the scale and all of its sub-dimensions. The sub-dimensions of the scale and confirmatory factor analysis were also confirmed by the fit criteria, and it is understood that this model is theoretically and statistically appropriate.

\section{Kaynakça / References}

Akkoyunlu, B. ve Orhan, F. (2003). Bilgisayar ve öğretim teknolojileri eğitimi (böte) bölümü öğrencilerinin bilgisayar kullanma öz yeterlik inanc ile demografik özellikleri arasındaki ilişki. The Turkish Online Journal of Educational Techno$\log y, 2(3), 86-93$.

Albayrak, C. ve Bulut, D. (2020). Güzel sanatlar lisesi viyolonsel öğrencilerinin çalgı performansı öz yeterlik inançlarına yönelik bir inceleme.TURAN:Stratejik Araştırmalar Merkezi, 12(46), 266-269.

Altındağ, M. (2008). Hacettepe üniversitesi eğitim fakültesi ö̆rencilerinin yürütücü biliş becerileri. Yayınlanmamış Yüksek Lisans Tezi, Hacettepe Üniversitesi, Ankara. 
Arseven, A. (2016). Öz yeterlilik: bir kavram analizi. Electronic Turkish Studies, 11(19), 63-80.

Babacan, E. ve Küçükosmanoğlu, O. (2015). Müzik eğitimi anabilim dalı öğrencilerinin zaman yönetimi becerileri. e-Uluslararası Ĕ̆itim Araştırmaları Dergisi, 6(2), 36-50.

Bandura, A. (Ed.) (1995). Self-Efficacy in changing societies. New York: Cambridge University Press.

Baydoğan, E. (2007). Kariyer yönetimi. Eğitişim Dergisi, 16, 1-13.

Bayramkaya, E. Toros, F. ve Cengiz, Ö. (2005). Ergenlerde sosyal fobi ile depresyon, öz kavram, sigara alışkanlığı arasındaki ilişki.Klinik Psiko farmakoloji Bülteni,15(4), 165.

Butler G. ve F. McManus (1998). Psychology; a veryshortinstruction. Oxford: Oxford UniversityPress.

Büyüköztürk, Ş. (2004). Veri analizi el kitabı. 3. Baskı, Ankara: Pegem .

Büyüköztürk, Ş. (2007). Sosyal bilimler için veri analizi el kitabı. 7. Baskı, Ankara: Pegem

Büyüköztürk, Ş. (2012). Sosyal bilimler için veri analizi el kitabı. Ankara: Pegem .

Büyüköztürk, Ş., Çakmak, E.K., Akgün, Ö.E., Karadeniz, Ş., ve Demirel, F. (2018). Bilimsel araştırma yöntemleri. 24. Bask1, Ankara: Pegem .

Çelik, A. ve Akgemci, T. (1998). Girişimcilik kültürü ve KOBI'ler. Ankara: Nobel Yayın Dağtım, s.238.

Çırakoğlu, O. C. (2013). Sahnedeki düşman: müzisyenlerde performans kaygısı üzerine bir gözden geçirme. Türk Psikoloji Yazıları, 16(32) 95-106.

Çorbacı, S. (2010). Illköğretim okullarnndaki performans yönetimi uygulamalarn ile yönetici ve öğretmenlerin örgütsel bağhllıkları arasındaki ilişki. Yayınlanmamış Yüksek Lisans Tezi, Sakarya Üniversitesi, Sakarya.

Daft, R. (1997). Management. 4. Basım, The Dryden Press, Florida.

Deci, E. And R. Ryan (2000). The what and why of goal pursuits: Human needs and the self-determination of behavior. Pychological Inquiry, 11(4), 227-268.

Dilmaç, O. ve İnanç, C. (2015). Sınıf öğretmenlerinin görsel sanatlar dersine yönelik öz yeterlik düzeyleri. Bartın Üniversitesi Ĕ̈itim Fakültesi Dergisi, 4(2), 382-400.

Doğan, C. ve Tecimer, B. (2019). Müzik öğretmenliği lisans programı öğrencilerinin müzik performans kaygı düzeyleri (Ankara-Gazi Üniversitesi Örneği). Bartın Üniversitesi Ĕ̈itim Fakültesi Dergisi, 8(2), 507-523.

Fındıkçı, İ. (1999). İnsan kaynakları yönetimi. İstanbul: Alfa Yayınları, s.343.

Gül, H. ve Avcl, M. (2018). Kurumsal itibarın kariyer yönetimi üzerindeki etkileri: KTMÜ örneği. KMÜ Sosyal ve Ekonomik Araştırmalar Dergisi, 20(34), 53-69. 
Gün, E. (2014). Piyano performansı öz yeterlik ölçeğinin geliştirilmesi ve uygulanması Yayınlanmamış Doktora Tezi, Mehmet Akif Ersoy Üniversitesi Eğitim Bilimleri Enstitüsü, Burdur.

Gün, F. ve Büyükgöze, H.(2015). Araştırma görevlilerinin bireysel gelişimin inisiyatifinde öz yeterliğin rolü. Bartın Üniversitesi Eğitim Fakültesi Dergisi, 4(2), 418432.

Helvac1, M. Akif (2002). Performans yönetimi sürecinde performans değerlendirmenin önemi. Ankara Üniversitesi Eğitim Bilimleri Fakültesi Dergisi, 35(1-2), 155169.

Hewett, R. (2016). Examining the relationship between workplace rewards and the quality of motivational experience; a self-determination theory perspective. Yayınlanmamış Doktora Tezi ,LondonÜniversitesi.

Ivancevich, J. Donnelly, J. ve Gibson, J. (1980). Managing for Performance. Business Publications, s.563.

Kan, A. (2014). Albert Bandura ve sosyal öğrenme kuramı. Öğrenme öğretme kuram ve yaklaşımları. (Ed: Filiz, S. B.), Ankara: Pagem Akademi Yayınevi.

Kalkandelen, H. (1997). Örgütlerde yeniden yapılanma ve norm kadro. Ankara: Anı Yayinları.

Karagöz, Y. (2017). SPSS ve AMOS uygulamal nicel-nitel-karma bilimsel araştırma yöntemleri. Ankara: Nobel Yayın Dağıtım.

Kutluca, A. Y. (2018). Öğretmen öz-yeterliğinin motivasyon ve epistemolojik ve pedagojik inanç sistemleri açısından incelenmesi. Cumhuriyet International Journal of Education, 7(2), 175-192.

Leech, N. L., Barrett, K. C., ve Morgan, G. A. (2005). SPSS for intermediate statistics: Use and interpretation. Lawrance Erlbaum Associates Publishers, London.

Locke, E. A., ve Latham, G. P. (1990). Work motivation and satisfaction: Light at the end of the tunnel. Sage Publications, Inc. onbehalf of the Association for Psychological Science, 1(4), 240-246.

Mayer, R. E. (2003). Learning and Istruction. New Jersey, Merril PrenticeHall.

Okakın, N.(2008).Kariyer yönetiminin bazı insan kaynakları fonksiyonları ile ilişkisi üzerine bir çalışma. Öneri, 8(30), 1-8.

Otacıoğlu, S. (2017). Müzik öğretmeni adaylarının öz etkililik-yeterlilik düzeylerinin incelenmesi. Kafkas Üniversitesi Sosyal Bilimler Enstitüsü Dergisi, 19, 171-178.

Özçimen, A. ve Burubatur, M. (2012). Eğitim fakülteleri müzik eğitimi ana bilim dallarında birinci sınıf 1 . ve 2. yarıyıl viyolonsel eğitiminde en çok kullanılan metot etüt ve egzersizler. Selçuk Üniversitesi Sosyal Bilimler Enstitüsü Dergisi, 27, 185-194. 
Öztürk, Ü. (2006). Organizasyonlarda performans yönetimi. İstanbul: Sistem Yayıncllk.

Peeters, M. A. ve Rutte, C. G. (2005). Time management behavior as a moderator for the job demand-control interaction.Journal of Occupational Health Psychology, 10, 64-75.

Pintrich, P. R. (2002). The role of meta cognitive knowledge in learning, teaching, and assessing. Theory In to Practice, 41(4), 219-225.

Pugh, D. (1991). Organizational behaviour. Prentice Hall Interneational, UK.

Şeker, S. S. (2016). Development of instrument performance self-efficacy scale/ çalgı performansına ilişkin öz-yeterlik ölçeğinin geliştirilmesi. Journal of Human Sciences, 13(3), 5150-5162.

Senemoğlu, N. (2007). Gelişim, öğrenme ve öğretim: kuramdan uygulamaya. 13. Bask1, Ankara: Gönül Kitabevi.

Slavin, R. E. (2000). Educational psychology: Theory and practice. Allynand Bacon, Boston. Şimşek, Ö.F. (2007). Yapısal eşitlik modellemesine giriş, temel ilkeler ve lisrel uygulamalar. Ankara: Ekinoks Yayınları.

Sipahi, B., Yurtkoru, E. S., ve Çinko, M. (2006). Sosyal bilimlerde SPSS'le veri analizi. İstanbul: Beta.

Tabachnick, B. G., ve Fidell, L. S. (2013). Using multivariate statistics. 6th edition, Pearson Education, Boston.

Tavşancil, E. (2006). Tutumlarm ölçülmesi ve SPSS ile veri analizi. Ankara: Nobel Yayın Dağıtım.

Tastepe, H. (2001). Kariyer yönetiminin değerlendirilmesi. Yayımlanmamış Yüksek Lisans Tezi, Sakarya Üniversitesi, Sosyal Bilimler Enstitüsü, İşletme Ana Bilim Dalı, Sakarya.

Uçan, A. (2018). Müzik eğitimi temel kavramlar-ilkeler-yaklaşımlar ve Türkiye' deki durum. Ankara: Arkadaş yayınevi.

Yağışan, N. (2004).Çalgı icracilarında kas-iskelet problemleri ve nedenleri. Selçuk Üniversitesi Sosyal Bilimler Enstitüsü Dergisi, 11, 561-574.

Yetik, S. S. (2017). Çevrimiçi öz düzenleyici öğrenme ortamında meta bilişsel desteğin öz düzenleme becerisine etkisi.Cumhuriyet International Journal of Education, $6(1), 107-122$.

Yıldız, C. (2014). Müziksel işitme, okuma ve yazma öz yeterlilik ölçeği'nin geliştirilmesi ve müziköğretmeni adaylarınn öz yeterlilik düzeylerinin bazı değ işkenler açısından incelenmesi. Yayımlanmamış Yüksek Lisans Tezi, İnönü Üniversitesi Eğitim Bilimleri Enstitüsü, Malatya.

Yolcu, S. (2008). İstanbul ili resmi ilköğretim okullarnnda öğretmen performans yönetimi. Yayınlanmamış Yüksek Lisans Tezi, Yıldız Teknik Üniversitesi. 
Yurt, E. ve Kurnaz, A. (2016). Özel yetenekli öğrencilerin matematik öz-yeterlik kaynaklarının matematik kayglları üzerindeki etkilerinin incelenmesi. Pegem Ĕgitim ve Öğretim Dergisi, 5(4), 347-360.

Yüner, B. (2018). Örgüt temelli öz saygı ve örgütsel duygusal bağlılığa ilişkin öğretmen görüşleri. Ankara Üniversitesi Ĕ̆itim Bilimleri Fakültesi Özel Ĕ̆itim Dergisi, 19(4), 777-799.

\section{Ek: Çalgı Performans Yönetimi Öz Yeterlilik Algısı Ölçeği}

\begin{tabular}{|c|c|c|c|c|c|c|}
\hline & $\begin{array}{l}\text { 1: Kesinlikle katılmıyorum/Bana hiç uymuyor, } \\
\text { 2: Katılmıyorum/Bana uymuyor, 3: Kararsızım, } \\
\text { 4: Katılıyorum/Bana uyuyor, 5: Kesinlikle katılıyorum/Bana ta- } \\
\text { mamen uyuyor }\end{array}$ & & & & & \\
\hline $\mathbf{A}$ & $\begin{array}{l}\text { KARIYYR YÖNETIMII } \\
\text { Çalgı performansımla ile ilgili ulaşmayı istediğim kariyer he- } \\
\text { definde, }\end{array}$ & 1 & 2 & 3 & 4 & 5 \\
\hline 1 & Uzun vadeli hedefler belirlerim. & & & & & \\
\hline 2 & $\begin{array}{l}\text { Kendimi ara ara gözlemler ve hedeflerim doğrultusunda yeni } \\
\text { değerlendirmeler yaparım. }\end{array}$ & & & & & \\
\hline 3 & $\begin{array}{l}\text { Performansımın değerlendirilmesi için alanında uzman kişiler- } \\
\text { den destek alırım. }\end{array}$ & & & & & \\
\hline 4 & $\begin{array}{l}\text { Çalgı tekniğimle ile ilgili eksiklerimi ve ihtiyaçlarımı fark eder ve } \\
\text { kariyer hedeflerimi bu doğrultuda planlarım. }\end{array}$ & & & & & \\
\hline 5 & $\begin{array}{l}\text { Müzikal eksiklerimi ve ihtiyaçlarımı fark eder ve kariyer hedef- } \\
\text { lerimi bu doğrultuda planlarım. }\end{array}$ & & & & & \\
\hline 6 & Belirlediğim hedeflerin gidişatı ile ilgili değerlendirme yaparım. & & & & & \\
\hline 7 & Sanatsal ve bilimsel etkinliklerde yer alırım. & & & & & \\
\hline 8 & Alanımda çıkmış yazılı kaynakları düzenli olarak takip ederim. & & & & & \\
\hline 9 & Karşıma çıkan kariyer fırsatlarını lehime çeviririm. & & & & & \\
\hline B & $\begin{array}{l}\text { ZAMAN YÖNETIMİ } \\
\text { Çalgı performansımla ilgili yapılması gereken işlerde zamanı } \\
\text { etkin kullanabilmek için, günlük olarak ya da ileriye dönük } \\
\text { olarak, }\end{array}$ & & & & & \\
\hline 10 & $\begin{array}{l}\text { Çalışmalarımın ayrıntılı olarak zamansal bir programlaya göre } \\
\text { planlarım. }\end{array}$ & & & & & \\
\hline 11 & $\begin{array}{l}\text { Çalışma planımda yaşadığım olumlu ve olumsuz koşullara bağlı } \\
\text { olarak, hedef-zaman ilişkisini tekrar yenilerim. }\end{array}$ & & & & & \\
\hline 12 & Çalışmalarımda belirlediğim zamana bağlı kalırım & & & & & \\
\hline 13 & Çalgı çalışmalarına ayırdığım zamanı etkin şekilde kullanırım. & & & & & \\
\hline 14 & $\begin{array}{l}\text { Çalışma planımın dışında oluşan boş zamanı, olumlu yönde kul- } \\
\text { lanmak üzere değerlendiririm. }\end{array}$ & & & & & \\
\hline 15 & $\begin{array}{l}\text { Çalışma planıma uyamadığım durumlarda kaybettiğim zamanı } \\
\text { telafi ederim. }\end{array}$ & & & & & \\
\hline
\end{tabular}




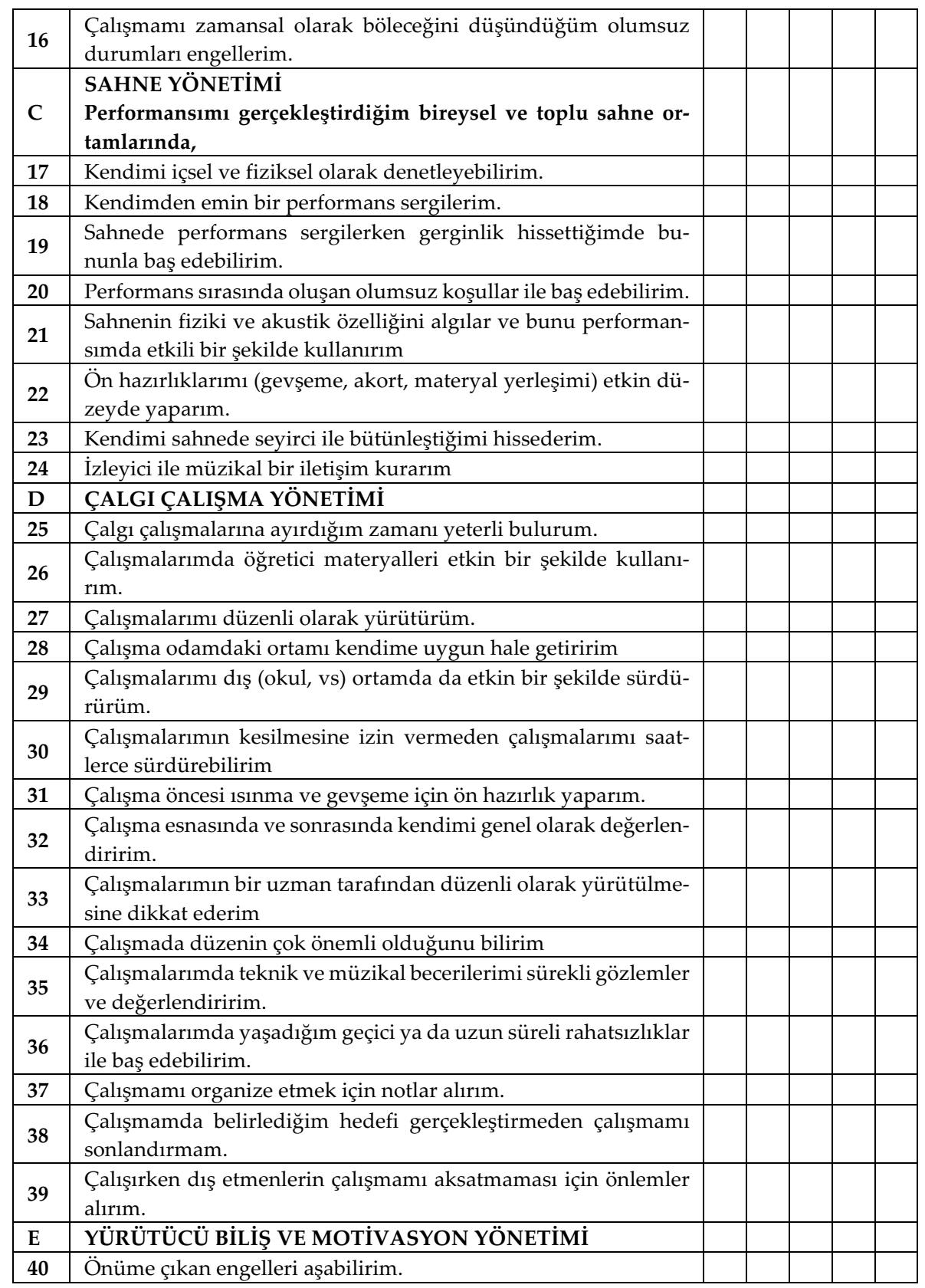




\begin{tabular}{|c|l|l|l|l|l|}
\hline $\mathbf{4 1}$ & $\begin{array}{l}\text { Karşılaştı̆̆ım/karşılaşabileceğim olumsuz durumlarda kendi be- } \\
\text { cerilerimi tekrar değerlendirip kariyer planımı lehime çevirebili- } \\
\text { rim. }\end{array}$ & & & & \\
\hline $\mathbf{4 2}$ & $\begin{array}{l}\text { Şimdiye kadar edindiğim müzikal bilgi, kişisel beceri ve dona- } \\
\text { nımlarımın ilerlememde engel taşımadığını bilirim. }\end{array}$ & & & \\
\hline $\mathbf{4 3}$ & $\begin{array}{l}\text { Kendimi gelmek istediğim yerde olduğumu hayal ederim / Ken- } \\
\text { dimi olmak istediğim yerde görebiliyorum. }\end{array}$ & & & \\
\hline $\mathbf{4 4}$ & $\begin{array}{l}\text { Kisa ve uzun vadeli hedeflerim doğrultusunda yaşadığım olum- } \\
\text { suzlukla baş edebilirim. }\end{array}$ & & & & \\
\hline $\mathbf{4 5}$ & Kendimi sık sık takdir ederim. & & & \\
\hline $\mathbf{4 6}$ & Yaşadığım olumsuzluklarda şevkimin kırılmasına izin vermem. & & & & \\
\hline $\mathbf{4 7}$ & $\begin{array}{l}\text { Çalışmalarımı planladığım şekilde tamamladığımda kendimi } \\
\text { ödüllendiririm. }\end{array}$ & & & \\
\hline
\end{tabular}

\section{Kaynakça Bilgisi / Citation Information}

Kubilay, Ü. C. ve Yorulmaz Birdal, Ö. (2021). Çalg1 performans yönetimi öz-yeterlik algısı ölçeği geliştirme çalışması. OPUS-Uluslararası Toplum Araştırmaları Dergisi, 17(38), 5125-5160. DOI: 10.26466/opus.8951048 